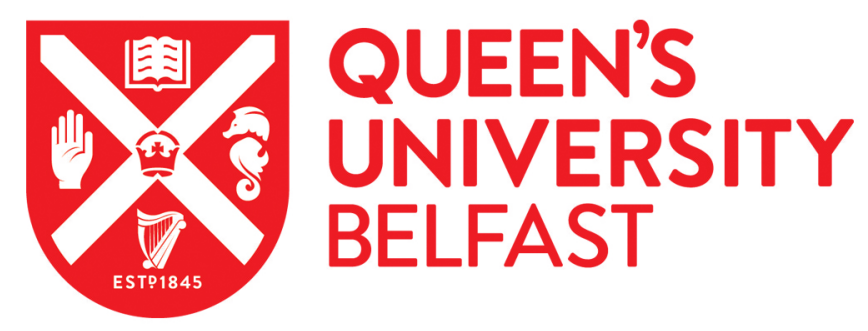

\title{
Women of an uncertain age: quantifying human capital accumulation in rural Ireland in the nineteenth century
}

Blum, M., Colvin, C. L., McAtackney, L., \& McLaughlin, E. (2017). Women of an uncertain age: quantifying human capital accumulation in rural Ireland in the nineteenth century. Economic History Review, 70(1), 187-223. https://doi.org/10.1111/ehr.12333

Published in:

Economic History Review

Document Version:

Peer reviewed version

Queen's University Belfast - Research Portal:

Link to publication record in Queen's University Belfast Research Portal

\section{Publisher rights}

(c) Economic History Society 2016.

This is the peer reviewed version of the following article: Blum, M., Colvin, C. L., McAtackney, L. and McLaughlin, E. (2017), Women of an uncertain age: quantifying human capital accumulation in rural Ireland in the nineteenth century. The Economic History Review, 70: 187-223, which has been published in final form at DOI: 10.1111/ehr.12333. This article may be used for non-commercial purposes in accordance with Wiley Terms and Conditions for Self-Archiving.

\section{General rights}

Copyright for the publications made accessible via the Queen's University Belfast Research Portal is retained by the author(s) and / or other copyright owners and it is a condition of accessing these publications that users recognise and abide by the legal requirements associated with these rights.

\section{Take down policy}

The Research Portal is Queen's institutional repository that provides access to Queen's research output. Every effort has been made to ensure that content in the Research Portal does not infringe any person's rights, or applicable UK laws. If you discover content in the Research Portal that you believe breaches copyright or violates any law, please contact openaccess@qub.ac.uk. 


\title{
Women of an uncertain age: quantifying human capital accumulation in rural Ireland
} in the nineteenth century*

\author{
By Matthias Blum, Christopher L. COlvin, \\ LAURA MCATACKNEY and EOIN MCLAUGHLIN ${ }^{\dagger}$
}

\begin{abstract}
Geary and Stark find that Ireland's post-Famine per capita GDP converged with British levels, and that this convergence was largely due to total factor productivity growth rather than mass emigration. In this article, new long-run measurements of human capital accumulation in Ireland are devised in order to facilitate a better assessment of sources of this productivity growth, including the relative contribution of men and women. This is done by exploiting the frequency at which age data heap at round ages, widely interpreted as an indicator of a population's basic numeracy skills. Because Földvári, van Leeuwen, and van Leeuwen-Li find that gender-specific trends in this measure derived from census returns are biased by who is reporting and recording the age information, any computed numeracy trends are corrected using data from prison and workhouse registers, sources in which women ostensibly self-reported their age. The findings show that rural Irish women born early in the nineteenth century had substantially lower levels of human capital than uncorrected census data would otherwise suggest. These results are large in magnitude and thus economically significant. The speed at which women converged is consistent with Geary and Stark's interpretation of Irish economic history; Ireland probably graduated to Europe's club of advanced economies thanks in part to rapid advances in female human capital.
\end{abstract}

\footnotetext{
* We thank Findmypast Ireland Ltd. for access to their digitized prison registers for Clonmel Gaol, and Eneclann Ltd. for help in expanding their content. We thank Jörg Baten, Graham Brownlow, Greg Clark, Brian Donovan, Joost Jonker, Liam Kennedy, Sean Lucy, Chris Minns, Niall Ó Ciósáin, Cormac Ó Gráda, Maarten Prak, Valeria Prayon, John Turner, Bas van Leeuwen, and conference and seminar participants at the European Historical Economics Society (London, Sept. 2013), the University of Edinburgh (Oct. 2013), Rijksuniversiteit Groningen (Nov. 2013), the Economic and Social History Society of Ireland (Galway, Nov. 2013), Queen's University Belfast (Nov. 2013 and April 2014), the University of Bath (April 2014), the University of Cardiff (April 2014), the Scottish Economic Society (Perth, April 2014), and Universiteit Utrecht (Dec. 2014) for comments and suggestions. We are especially indebted to the editors and three anonymous referees for showing us how to improve the original submission to this journal. We acknowledge funding from the Erasmus Staff Mobility Programme (Blum), the Economic History Association (Colvin), and the University of Edinburgh Challenge Investment Fund (McLaughlin).

${ }^{\dagger}$ Author Affiliations: Blum, Queen’s University Belfast (matthias.blum@qub.ac.uk); Colvin, Queen’s University Belfast (chris.colvin@qub.ac.uk); McAtackney, Aarhus Universitet (laura.mcatackney@cas.au.dk); McLaughlin, University of St Andrews (eoin.mclaughlin@st-andrews.ac.uk).
} 
U sing a method for allocating country-level GDP estimates across regions, Geary and Stark argue that there was weak growth convergence in Post-Famine Ireland, with per capita GDP growing faster than that of Great Britain. ${ }^{1}$ Indeed, they conclude that Ireland's growth record was good enough to locate the island's economy among the world's most advanced by the late-nineteenth century. Geary and Stark's main contribution to Irish economic history has been to revise down the role of emigration in the overall explanation for Post-Famine economic performance; they conclude that less than one third of Ireland's labour productivity gains between 1861 and 1911 were due to its labour force decline, with the bulk of productivity growth being explained instead by more traditional forces: capital accumulation and total factor productivity (TFP) growth. ${ }^{2}$ This important finding demands more accurate measurement of the various components of TFP, such as human capital. We attempt to contribute by doing exactly that: we construct and interpret new measures of human capital covering the period of Ireland's growth convergence. We remain acutely aware of the risk that any growth in human capital accumulation may be underestimated if the stock of human capital is overestimated at any one time, and so we use a variety of sources that alleviate the problems associated with gender inherent in conventional census-derived measures. ${ }^{3}$

As a residual in growth accounting, TFP cannot be measured directly; it is the total output not caused by given inputs in the underlying production function. While technological advancement and efficiency are traditionally regarded as the biggest drivers of TFP growth, 'new' theories of economic growth have increasingly focused their attention towards human capital accumulation. ${ }^{4}$ Theoretical growth models are now built around hypotheses linking the knowledge and skills embodied in humans directly with productivity outcomes and the overall ability to develop and exploit new technologies. ${ }^{5}$ Empirical research linking human capital and TFP growth has proved to be largely consistent with the predictions of these models. ${ }^{6}$ Policymakers have been keen to discuss and strategize their response to these literatures, also in the Irish context. ${ }^{7}$ Among economic historians, the work of Lindert in

\footnotetext{
${ }^{1}$ Geary and Stark, 'Examining', pp. 926-928.

${ }^{2}$ Ibid., p. 930 and 'Regional GDP', pp. 14-16. This revisionist view contrasts with the more traditional interpretation of Kennedy, Giblin and McHugh, Economic development, p. 18.

${ }^{3}$ Földvári, Van Leeuwen and Van Leeuwen-Li, 'How did women count?'.

${ }^{4}$ Crafts, 'Exogenous or endogenous growth?'.

${ }^{5}$ Lucas, 'On the mechanics'. Human capital is also a major component of 'Unified Growth Theory' (see Galor, Unified growth theory).

${ }^{6}$ Mankiw, Romer and Weil, 'A contribution'. The various contributions to Burton-Jones and Spender, The Oxford Handbook, offer an accessible review of the recent literature on human capital.

${ }^{7}$ Kavanagh and Doyle, 'Human capital'.
} 
particular has demonstrated a positive relationship between education and growth. ${ }^{8}$ Understanding secular variation in human capital accumulation over the long run - including periods which simultaneously encapsulate radical changes in both education policy and economic performance - is an important way in which historical economics can contribute. ${ }^{9}$ To this end, this current article provides and analyses a new long-run dataset on human capital for the Irish case for a period characterised by Geary and Stark as experiencing TFP-driven growth. If Geary and Stark are correct, then we expect to document substantial advances in human capital in the second half of the nineteenth century.

In particular, we focus on measuring educational attainment rather than just indicators of school attendance. We measure educational attainment through focusing on basic numeracy, which we estimate by investigating the systematic misreporting of age statements in social data: a phenomenon known as 'age-heaping'. ${ }^{10}$ Age data often display excess frequencies at round or attractive ages, such as even numbers and multiples of five, leading to heaped distributions. With various co-authors, Baten has found evidence of age heaping across both time and space, and argues that its temporal disappearance has been due to changes in peoples' basic ability to count, itself in part the result of improvements in educational attainment. ${ }^{11}$ A society's propensity to age heap is therefore linked directly with its overall level of human capital; trends in age heaping reveal trends in human capital accumulation. In addition to measuring male heaping, we produce series for women, a thus far largely neglected societal group. Measuring any secular trend in female human capital accumulation is particularly important, not just because of the direct role of women in Ireland's nineteenth-century labour markets, ${ }^{12}$ but also because of their continued centrality to household production and positive externalities on the education of subsequent generations. ${ }^{13}$

Studies of age heaping have used a variety of different sources, including census returns, ${ }^{14}$ migrant registers, ${ }^{15}$ court records,${ }^{16}$ household registers, ${ }^{17}$ marriage registers, ${ }^{18}$ and even portrait

\footnotetext{
${ }^{8}$ Lindert, 'The rise of social spending' and Growing public.

${ }^{9}$ A good example of such work is Barro and Lee, 'A new data set', who measure education enrolment across 146 countries from 1950 to 2010 .

${ }^{10}$ We follow a methodology used in A'Hearn, Baten and Crayen, 'Quantifying quantitative literacy'.

${ }^{11}$ For an overview, see Crayen and Baten, 'Global trends'.

${ }^{12}$ Information on the importance of female labour in the economy can be deduced from census occupation returns (Census of Ireland, 1851-1911). In 1841 and 1851, females comprised 32\% of the labour force. In 1881, 34\% of the labour force was female, declining to $25 \%$ in 1911 . But this is likely to be an underestimate (see also statistics in: Geary, 'Regional industrial structure', table 1 and p. 170; Begley, Geary and Stark, 'Convergence', p. 10).

${ }^{13}$ Klasen, 'Low schooling for girls'.

14 Juif and Baten, 'Human capital'.

${ }^{15}$ Stolz and Baten, 'Brain drain'.
} 
paintings. ${ }^{19}$ The most popular source to date has probably been the census, which benefits from covering all people living in a society rather than just some subset thereof. But one uncertainty regarding the reliability of numeracy estimates from studies that use census data derives from the high likelihood that family household heads, usually male, report the ages of all family members in their census returns. ${ }^{20}$ Földvári, Van Leeuwen and Van Leeuwen-Li (henceforth FVV) find that married women tend to heap significantly less than unmarried women in studies based on such data. ${ }^{21}$ This suggests that a percentage of women have their ages adapted to that of their spouse and so female heaping patterns merely reflect male numeracy skills. FVV's solution is to exclusively use data pertaining to unmarried women. However, such a sample itself presents a problematic selection bias; evidence suggests that women who are successful in the marriage market tend to display superior human capital levels. ${ }^{22}$

We contribute to this broader methodological debate by adopting an alternative approach. We compare male and female numeracy estimates derived from three independently constructed sources spanning most of the nineteenth century for the case of rural Ireland: prison registers, workhouse records and corresponding census districts. ${ }^{23}$ Female numeracy estimates derived from Ireland's census potentially suffer from the 'FVV bias' as census forms were completed by household heads,

\footnotetext{
${ }^{16}$ Baten and Fourie, 'Numeracy of Africans'.

${ }^{17}$ Baten and Sohn, 'Early numeracy'.

${ }^{18}$ De Moor and Van Zanden, "'Every woman counts"”.

${ }^{19}$ De Moor and Zuijderduijn, 'The art of counting'.

${ }^{20}$ As A'Hearn, Baten and Crayen argue in 'Quantifying quantitative literacy', it is 'prudent as a check' alternative sources in order to discern any problems associated with the biases resulting from the reporting and recording of age statements (p. 795).

21 'Földvári, Van Leeuwen and Van Leeuwen-Li, 'How did women count?'.

${ }^{22}$ Becker, 'A theory of marriage', p. 813, theorises that 'men differing in physical capital, education or intelligence [...] will tend to marry women with like values of these traits'. Evidence suggests that educational investments are responsive to marriage market conditions (Boulier and Rosenzweig, 'Schooling'), and that marriage market outcomes are determined by assortive matching - e.g. wealthier brides marry wealthier grooms (Fafchamps and Quisembing, 'Assets at marriage'). Specifically in relation to the debate in this paper, Stolz, 'Essays on human capital formation', argues that FVV's findings are the result of an (upward) selection bias among married women rather than a marriage-related bias of age statement.

${ }^{23}$ The National Archives of Ireland holds the surviving records of all prisons located geographically within the modern borders of the Republic of Ireland (National Archives of Ireland, Dublin, Pris1). Data on a sample of Irish workhouses is compiled by Virginia Crossman, 'Welfare regimes under the Irish Poor Law 1850-1921', UK Data Archive. Published censuses in 1841 and 1871, available from Parliamentary Papers, provide year-by-year age distributions of the population of Ireland at the county level.
} 
who were usually male: ${ }^{24}$ census enumerators 'ask[ed] the age of every individual from the head of the family'. ${ }^{25}$ In contrast, incarcerated males and females stated their own ages independently at the time of their imprisonment, ${ }^{26}$ avoiding this problem and permitting us to estimate their 'true' age heaping pattern. ${ }^{27}$ Similarly, workhouse inmates self-reported their ages on arrival. ${ }^{28}$ The analysis of this article allows us to assess whether, and if so, to what degree Irish female numeracy is biased if based on census data alone. Census data on Ireland's female population serves as the potentially biased 'test group'. We then use female prison and workhouse inmates and their age statements as the 'control group'. We estimate male and female age heaping trends individually using census, prison and workhouse data and calculate first differences. We then use the differences in these differences to correct biases in age heaping-derived estimates of the human capital of the overall population across 12 decadal birth cohorts, between the 1770s and 1880s.

We find strong evidence of an FVV bias in Ireland's census returns. Using the registers of Clonmel Gaol as our benchmark comparison - a sample of 10,222 women and 27,693 men imprisoned between 1848 and 1910 - we estimate that women's ability to count in County Tipperary is hugely overestimated by the census; one third rather than two thirds of Tipperary's women born in the 1810s had basic numeracy skills. We find similar evidence that census measures of female numeracy are overestimated using workhouse data - a sample of 2,631 women and 4,654 men over a 50 -year period. Given the lower starting point of women in our prison benchmark and also in the workhouse sample, we conclude that the rate of convergence in human capital attainment was much

\footnotetext{
${ }^{24}$ Ireland had a strong patriarchal society, more so than anywhere else in Europe, thus household heads were invariable male; by the 1920s, Ireland was the only part of Europe where males survived females at any age (Ó Gráda, A rocky road, p. 207).

25 'We resolved to adopt the course of sending a form of return to each family, to be filled by its head, as less intrusive than requiring it to be filled by the enumerator from viva voce inquiry. But we, of course, took means to check the returns so obtained, and required from the enumerator a certificate that they were true to the best of his belief', Report of the commissioners, p. v \& p. xlv.

${ }^{26}$ Rule number 10 of the general prison rules of 1888 states that 'the name, age, religious denomination, height, weight, features, particular marks, and general appearance of a prisoner shall, upon his admission, be noted in a nominal record of prisoners to be kept by the Governor', Copy of rules and regulations.

${ }^{27}$ In cases where a prisoner does not know her own age, it is unclear from our sources whether it is that prisoner or her prison admission officer who estimates her age. We argue that this is immaterial in a large dataset; both cases suggest that the prisoner is innumerate.

${ }^{28}$ Crossman notes that 'once admitted to a workhouse, the pauper's name and religion was entered in the admission register and they were sent to the probationary ward, where they remained until being examined by the medical officer' (Crossman, Poverty, pp. 112-113).
} 
more rapid than previously thought. ${ }^{29}$ The speed of this convergence is consistent with the view that Ireland's Post-Famine catch-up with British levels of per capita GDP must be at least partly due to TFP growth. ${ }^{30}$ Our estimates of improvements in the stock of human capital provide evidence to support the revisionist views of Geary and Stark, and suggest that females may have disproportionately driven these improvements.

\section{I: Schooling, education, and human capital attainment}

Nineteenth-century Ireland was an impoverished sophisticate: despite its poverty there was a demand for education from its peasantry. ${ }^{31}$ Basic literacy was already common across Ireland in the early nineteenth century. ${ }^{32}$ 'Hedge schools' were found in almost every parish in the country prior to the introduction of state-funded education. These 'schools' were reported to have had a wide and varied curriculum; parental demand led to arithmetic being taught alongside scripture. ${ }^{33}$ By 1824 there were approximately 9,000 such schools. ${ }^{34}$ They were attended by Roman Catholics and Protestants alike, with the majority of hedge schools being de facto multi-denominational in character. ${ }^{35}$ Then, in 1831 , Ireland became the first polity of the United Kingdom to receive state-funded primary education. ${ }^{36}$ The new national schools that were established were promoted to teach numeracy alongside literacy and, as Clarke illustrates, bookkeeping was a sought after subject taught in hedge schools and national schools alike. ${ }^{37}$

How well did girls do relative to boys from Ireland's new educational settlement? FitzGerald calculates that 35 per cent of boys and girls of between the age of six and 13 attended schools at the time of Ireland's 1821 census - 44 per cent of boys and 26 per cent of girls. ${ }^{38}$ Attendance improved

\footnotetext{
${ }^{29}$ A similar conclusion is drawn from the analysis of prison data from other parts of the island, both more urban (Kilmainham Gaol, Dublin) and more rural (Castlebar Gaol, County Mayo) than Tipperary. The results of this exercise are reported in an appendix to this article, and the underlying regression analysis is available from the authors upon request.

${ }^{30}$ As Kennedy, Giblin and McHugh (Economic development, p. 22) illustrate, income per capita in the industrialising north of Ireland was at most $10 \%$ higher than in the south, thus our findings may be considered sufficiently representative of the whole of the island for most of the time period under analysis.

${ }^{31}$ Akenson, Irish education experiment, p. 17; Mokyr and Ó Gráda, 'Poor and getting poorer?'

${ }^{32}$ Ó Gráda, 'School attendance', p. 114.

${ }^{33}$ McManus, The Irish hedge school, p. 60.

${ }^{34}$ Ibid., p. 20, 31.

${ }^{35}$ FitzGerald, Irish primary education, p. 111.

${ }^{36}$ The precociousness of the Irish state-financed system is evident in the $1870 \mathrm{~s}$, when central funding for schools in Ireland was $85 \%$ of total funds compared to $35.5 \%$ in England and Wales (Lindert, Growing public, vol. 1, pp. 116-117).

${ }^{37}$ Coolahan, Irish education; Clarke, 'The teaching', p. 23.

${ }^{38}$ Ó Gráda, ‘School attendance’, p. 117.
} 
substantially across the century, especially following the Great Famine; by the 1880s, if there was a gender difference, then it was reversed. ${ }^{39}$ By the time attendance was made compulsory in 1892, few, if any, children had not spent at least some time at school. ${ }^{40}$ Comparing enrolment with attendance data, however, suggests a need for more informative measures of human capital acquisition during childhood; in 1861 the enrolment rates of male and female students were 67 and 66 per cent, but attendance rates were less than half of this. By 1901 female enrolment rates had superseded those of male students, 84 per cent compared to 79 per cent, and attendance rates had approximately doubled (to 53 per cent). ${ }^{41}$ What impact did this have on relative trends in educational attainment?

While datasets relating to literacy are available from the Irish censuses, these are somewhat unsatisfactory as they only provide information on those aged over five who can read and write or those who are partially literate. Using these sources we can see that illiteracy (those who could neither read nor write) fell from 45 per cent for males in 1841 to 14 per cent in 1901 . The decrease in female illiteracy was more striking, declining from 57 per cent to 14 per cent over the same timespan. ${ }^{42}$ Recent estimates of educational attainment by Morrison and Murtin suggest that average years of schooling of the population aged 15 to 64 increased from 2.15 years in 1871 to 4.46 years in $1901{ }^{43}$ However, these estimates are essentially data constructs, as they apply a number of assumptions to data on school enrolments from Mitchell's International historical statistics. ${ }^{44}$

In conclusion, existing measures of educational attainment are unsatisfactory in the case of Ireland; while we know a great deal about trends in school attendance, we know relatively little about schooling outcomes and cognitive ability, especially numeracy. ${ }^{45}$ This article begins to address this gap in our understanding. We measure the numeric ability of cohorts of people that were exposed to Ireland's increasingly more sophisticated education system by analysing self-reported ages of women and men entering the prison system in Clonmel, a garrison town located in County Tipperary, and the

\footnotetext{
${ }^{39}$ Fitzpatrick, "“A share of the honeycomb”, p. 219.

${ }^{40}$ Logan, 'Sufficient for their needs'.

${ }^{41}$ Rates are expressed as a percentage of the cohort aged 5-14 from census records. Data on enrolments and attendance are from Twenty-eighth report and Sixty-eighth report.

${ }^{42}$ Note that an FVV bias is also theoretically possible for literacy rates.

${ }^{43}$ Morrisson and Murtin, 'The century of education'.

${ }^{44}$ The underlying data of Morrisson and Murtin are a mixture of enrolment and attendance for various countries; the Irish data are average attendance for primary schools, but do not contain any data for secondary or university education. Morrisson and Murtin appear to have overlooked Mitchell's observation that 'of all the subjects on which statistical material exists, none (not even crime) shows less uniformity, both over time and between countries, than education' (p. 867).

${ }^{45}$ Hippe, 'How to measure human capital?', finds that improvements in numeric ability tend to precede improvements in literacy.
} 
workhouse in Thurles, a cathedral town 25 miles to its north. Tipperary was predominantly agricultural prior to the 1820s; Clonmel and Thurles had proto-industrial sectors. Each is introduced below.

Tipperary had some of the finest agricultural land on the island and was an early convert from tillage to pasture. This insulated it somewhat from the catastrophic effects of potato crop failure: Tipperary features only about midway down Mokyr's league table of Famine-related deaths. ${ }^{46}$ In the Post-Famine period Tipperary continued its shift towards pasture and in the final years of the nineteenth century was a leader in the Irish dairy industry with the highest concentration of creameries on the island. ${ }^{47}$ However, there was a decreasing share of the population whose occupations are defined as 'skilled' according to the Armstrong scale - declining from 20 per cent to eight per cent of the total occupations - thus reflecting a decline of industrial occupations. ${ }^{48}$ Fitzpatrick ranks Tipperary as having above-average female literacy by 1871, partly, he argues, because employing children was considered less profitable there than elsewhere on the island. ${ }^{49}$

Clonmel was a major regional market town located in the River Suir valley. Writing in 1907, Burke argued that it 'became one of the greatest grain markets of the kingdom; for except a comparatively small amount went by canal to Limerick and Dublin, the whole corn of Tipperary and the neighbouring counties passed through the town'. ${ }^{50}$ Clonmel had a large number of food processing outlets, such as flourmills, breweries and distilleries, and was active in butter trade and manufacturing. ${ }^{51}$ The town also had a cotton factory. In addition, Clonmel had a long history of banking, hosting a branch of the infamous Tipperary Joint Stock Bank, which was spectacularly defrauded in $1856 .{ }^{52}$ According to Burke, 'in no direction was the progress of Clonmel more marked than in education'. Burke lists several public schools for boys and girls that were in existence in the town by the mid-nineteenth century. Thurles, a town located more upriver, was roughly half the size of Clonmel, but was similar to it in many respects. It was a business and financial centre for its surrounding hinterland and possessed an industrial base of brewing and tanning. ${ }^{53}$ The town was also a religious centre for Tipperary, hosting the mother church of the Archdiocese of Cashel and Emly.

\footnotetext{
${ }^{46}$ Mokyr, Why Ireland starved, p. 267.

${ }^{47}$ McLaughlin, 'Competing forms', p. 100.

48 Calculated from the 1841 census of Ireland (Report of the commissioners) using the classification outlined in Armstrong, 'The use of information'.

${ }^{49}$ Fitzpatrick, "“A share of the honeycomb”, pp. 220; 230-231.

${ }^{50}$ Burke, History of Clonmel, p. 182.

${ }^{51}$ Ibid., pp. 182-195.

${ }^{52}$ O'Shea, Prince of swindlers.

${ }^{53}$ Ó Gráda, 'Savings banks', pp. 39-40.
} 
In an early application of age heaping, Mokyr and Ó Gráda found that Ireland's emigrants exhibited high levels of heaping, ${ }^{54}$ leading Mokyr later to conclude that 'emigrants tended to heap more, not less, than those who remained behind' ${ }^{55}$ Fitzpatrick argues that those Irish women who stayed behind on the island - about half of each generation - sought instead to better themselves through education. ${ }^{56}$ Overall, he finds that those areas of the island that experienced the highest level of emigration saw the most rapid educational improvements of women as they, or indeed their parents, sought to improve their chances of making it in foreign labour markets. ${ }^{57}$ Cohort depletion rates, a measure of emigration favoured in studies of Ireland, suggest that female emigration was lower than that of males in Tipperary until the $1880 \mathrm{~s} .{ }^{58}$ Family unit migration was more common in the early nineteenth century, after which young males and females migrated independently. ${ }^{59}$

Does Tipperary's experience of migration explain the pattern of educational attainment found there? In a multivariate analysis of the drivers of Post-Famine Irish migration, Hatton and Williamson find that education was not an important cause. ${ }^{60}$ Instead, the factors that account for Irish emigration were poverty, demographic pressures and smallholdings. But while education may not drive migration, Fitzpatrick's argument primarily concerns those that were left behind; migration may drive demand for education. Any secular trend found in education measures for Tipperary therefore still requires an explanation. We add to this debate by estimating numeracy, a measure of educational attainment that is better than school attendance since numeracy reflects the outcome of parenting, education and schooling. We also compare our numeracy estimates with those derived from Tipperary-born inhabitants of England and Wales in order to reassess the findings of Mokyr and Fitzpatrick.

How exactly does education fit with the revisionist Geary and Stark Post-Famine productivity view? One obvious channel through which schooling can affect productivity is through education's positive externalities. Such externalities may exist either by increasing the productivity of educated workers, generating productivity spill-over effects, or by making the populace more amenable to technological adoption and invention. It may also generate social externalities, such as reducing crime

\footnotetext{
${ }^{54}$ Mokyr and Ó Gráda, 'Emigration and poverty', pp. 375-378.

${ }^{55}$ Mokyr, Why Ireland starved, p. 246.

${ }^{56}$ Fitzpatrick, "“A share of the honeycomb", p. 217.

${ }^{57}$ Ibid., pp. 227-228

${ }^{58}$ The migration statistics for Ireland do not fully account for the scale of emigration (Ó Gráda, 'A note'). We therefore follow Fitzpatrick's methodology of calculating cohort depletion, which is the percentage depletion over an intercensal period of the cohort initially aged 15-24 years in the Census of Ireland (Fitzpatrick, 'Emigration', p. 608).

${ }^{59}$ Fitzpatrick, 'Emigration', pp. 574-575.

${ }^{60}$ Hatton and Williamson, 'After the famine', p. 595.
} 
or creating a more civic population. The externalities may be inter-generational - more educated parents may have a positive impact on the current generation - or lead to improvements in health and morbidity. The link between education and growth has been explored in recent micro- and macrostudies of the returns to education and although there are serious biases estimating private and social returns, a consensus has emerged that suggests the existence of large and positive externalities. ${ }^{61}$ Breton argues that public returns can be higher than private returns in low-income countries. ${ }^{62}$ As these benefits accrued slowly over time, he argues that they have mistakenly been attributed to technological progress rather than rising levels of schooling. Assessing the existence and scale of positive externalities for the Irish case is beyond the scope of this present article. What we can show, however, is that there were significant increases in human capital attainment simultaneous to Ireland's educational advances - a correlation compatible with the Geary and Stark narrative.

\section{II: Prisons and workhouses}

Irish prison registers are a wealth of information and age data taken from these registers enable us to make the methodological innovation of this paper. A precedent for using Clonmel Gaol's registers comes from Ó Gráda's study of Clonmel inmates' heights, which he uses to explore the nutritional status of the Tipperary populace in the 1840s. ${ }^{63}$ A short history of prisons and their residents is necessary in order to contextualise this source and its potential biases. The prison system in nineteenth-century Ireland was localised and operated within a socio-political context that varied considerably from England. ${ }^{64}$ The numbers, uses and forms of prisons fluctuated greatly over the course of the century and were particularly affected by legislative change and major societal tumults. In 1822 there were 178 prisons in Ireland, the majority being dungeons attached to manorial courts or urban debtors jails, with the remainder being local 'Bridewells' attached to police stations or courthouses and housing those on remand or serving time for less serious crimes. ${ }^{65}$ In the early nineteenth century the majority of prison buildings were not custom-built; only five purpose-built prisons existed in $1823 .{ }^{66}$ This meant there was no facility for implementing increasingly more popular reformist ideas, such as segregation and classification.

\footnotetext{
${ }^{61}$ Krueger and Lindhal, 'Education for growth'; Hall, 'Positive externalities'; Dalmazzo and de Blasio, 'Production and consumption'; Choi, 'How large'.

${ }^{62}$ Breton, 'Schooling and national income', p. 78 and 'Corrected estimates', p. 456.

${ }^{63}$ Ó Gráda, 'Heights in Tipperary in the 1840s'.

${ }^{64}$ McConville, Irish political prisoners, p. 1.

${ }^{65}$ O’Donnell, Clonmel, p. 31.

${ }^{66}$ McDowell, The Irish administration. pp. 145-151.
} 
Legislative changes affected the administration and provision of prisons in Ireland. New laws (in 1810 and 1826) introduced a more uniform prison administration. ${ }^{67}$ However, the most radical change occurred in 1877 when the General Prisons Board was set up to centralise the control of all prisons. Following the professionalization of the prison system, only 23 of the 137 prisons in existence in Ireland in 1877 were still open in $1924 .{ }^{68}$ Clonmel Gaol, which housed criminals from across County Tipperary and some immediate surrounding areas, continued to function throughout this latter period of reform. The ending of transportation of Ireland's convicts to Australia in 1853 led to reviews of conditions and forms of imprisonment, which resulted in the creation of the Irish Convict System, introduced to all prisons following the 1877 legislation. ${ }^{69}$

As well as administrative changes, prisons were greatly affected by the huge upheavals in the mid-century due primarily to the social, economic and political turmoil engendered in the Great Famine (1845-1852). On its broadest level the Famine resulted in prisons throughout the country being their most overcrowded and unmanageable. This was due to increased rates of petty crimes resulting from desperation and starvation, the deliberate committing of crimes in the widespread belief that larger food rations were provided in prisons compared to workhouses, and the introduction of the Vagrancy Act (Ireland) $1847 .^{70}$ This law was passed not only to outlaw begging, but also to specifically target what was considered the growing threat of recidivist criminals. A more long-term impact of the Famine was a greater demand for land and general legal reforms, as well as a rise in more aggressive nationalist politics. Clonmel Gaol held a number of political prisoners, including initially the leaders of the failed Young Irelanders rebellion in 1848. Tipperary had a long tradition of Whiteboyism, rural violence aimed at socio-political grievances, with Whiteboys derived from varied social backgrounds. ${ }^{71}$ It had the highest homicide rates in the country during the 1830 s and 1840 s, but these fell dramatically in the later nineteenth century. ${ }^{72}$

The surviving prison registers that are accessible via the National Archives of Ireland, and used in our study, do not cover the full period of the prisons' existences. While the prison situated on Richmond Street in Clonmel dates from the late eighteenth century, ${ }^{73}$ the prison registers cover the period 1840 to 1924 . While the absence of registers for the early nineteenth century is disappointing,

\footnotetext{
${ }^{67}$ Ibid., p. 31.

${ }^{68}$ O’Donnell, Clonmel, p. 33.

${ }^{69}$ Carroll-Burke, Colonial discipline, p. 95.

${ }^{70}$ The Law Reform Commission, Report on vagrancy, p. 6.

${ }^{71}$ Beames, 'Rural conflict', p. 75, 86.

${ }^{72}$ Decade average homicide rates in Tipperary were 8.4 per 100,000 capita for the 1830 s, and 6.1 per 100,000 capita for the 1840s. This compares to the national average of 2.8 and 1.9 homicides (McMahon, Homicide, tables 1.1 and 1.2).

${ }^{73}$ O’Donnell, Clonmel, pp. 31-34.
} 
the surviving registers provide sufficient data to track numeracy for birth cohorts from before, during and after the Great Famine. Moreover, our data encompass all the major judicial and penal reforms of the period.

As an institutional comparison with prisons, we also use data from another nineteenth-century institution: the workhouse. The Irish poor law, introduced in 1838, established a system of publicly provided poor relief funded by a tax on the owners (landlords) and holders (farmers) of landed property. ${ }^{74}$ The system as introduced was intended to be a parallel to the 'new poor law' of England and Wales, ${ }^{75}$ but there were important differences in administrative structures, funding sources, the relationships between institutions and criteria for admission. ${ }^{76}$ The laws saw Ireland divided into a number of poor law unions, with each union having its own workhouse where local poor could go to receive relief. There were just four workhouses in 1840, increasing to 113 in 1844, 129 in 1847 and 163 by 1851 .

The Irish poor law was intended to provide a safety net for those who were unable to care for themselves out of their own resources; however it was designed so that the poor would not get the 'comfort' of outdoor relief, instead having to reside in the workhouse. ${ }^{77}$ The frugal and cruel nature of the system aimed to discourage the overuse of the poor law. It was opposed and resented by many of those who had to fund it. ${ }^{78}$ As with Ireland's prisons, the Famine exerted an influence on the poor law system, with an introduction of outdoor relief in the form of 'soup kitchens'. It also led to the introduction of the infamous 'Gregory clause', which required peasant farmers to surrender their land if they wished to use the poor law. ${ }^{79}$ The numbers in the workhouses swelled during the Famine resulting in severe overcrowded and high mortality rates.

\footnotetext{
${ }^{74}$ Poor Relief (Ireland) Act, 1838 ( 1 \& 2 Vict.), c. 56, section lxi. While funded by the taxpayer, there were some loans given by central government to pay for the initial outlays of the programme.

${ }^{75}$ George Nicholls, one of the architects of the Irish poor law system, was a poor law commissioner in England (Nicholls, A history; Crossman, Politics, pauperism and power, p. 10).

${ }^{76}$ Cox, Negotiating insanity, pp. 169-194. These differences were especially evident in the treatment of the mentally ill. Workhouses admitted only the 'pauper insane' until changes in the 1860 s dropped destitution as a necessary criterion for medical admission. This change enabled workhouses to warehouse the most chronic 'incurable' mentally ill (pp. 170-176). 77 The Irish poor law is seen as harsher than the English law, where the poor always had access to outdoor relief (Crossman, Politics, pauperism and power, p. 11).

${ }^{78}$ O'Connor, The workhouses of Ireland, p. 63. The introduction of a poor law was opposed by political economists but was supported by many on humanitarian grounds. The Irish Catholic church was also supportive and the idea received popular public support in England. However, the system as introduced overlooked a large volume of evidence on best practice in favour of a 'dogmatic' survey (Black, Economic thought, pp. 90-101, 109-110; Gray, The making).

${ }^{79}$ O'Connor, The Workhouses of Ireland, p. 139.
} 
Post-Famine workhouses were a refuge for the poorest of the population, as well as the old, ill and infirm. Their admission registers provide a possible counterpoint to the prison registers. Workhouses were prison-like in their material structure and plan, but also in how the residents were treated. In many ways their movements and actions were controlled like inmates, with at least theoretical separation dependant on their classification, wards locked at night, permission necessary to leave, and breakouts punished with prison sentences. Workhouses contained schools and taught basic literacy skills alongside religious doctrine. Crossman argues that entry to the workhouse was seen as a test of absolute poverty and that people could be denied entry if they were deemed to be able to support themselves (i.e. young and healthy), or if they could rely on someone else. ${ }^{80}$ Married women in particular could be denied entry to a workhouse if it was believed that their husbands were able to provide support.

In this study, we follow Crossman and use data pertaining to Post-Famine inmates from the Thurles workhouse. ${ }^{81}$ A significant number of inmates at Thurles were in for only one night (39 per cent in 1871, increasing to 77 per cent in 1889), and long-term residents (more than 180 days) made up about 10 per cent of the workhouse population. About half of the 'one-nighters' were men, and one quarter each for women and children. Workhouses also experienced 'recidivism', but categorisation and separation of the workhouse inmates was not as strict as in their English counterparts.

\section{III: Age heaping and human capital measurement}

When asked about their age, individuals who do not know it, are unable to calculate it by subtracting their year of birth from the current calendar year, or live in a society which deems such information not to be very useful, tend to round it to the nearest number ending zero or five. ${ }^{82}$ Age heaping, the pattern that results from such rounding, is interpreted by Baten and others as a measure of the supply of basic numeracy skills in a population. However, demand is also important. ${ }^{83}$ Knowing one's age is quite different to being able to count for purposes of paying rent or interacting in markets. Ireland in the early-nineteenth century was an increasingly more commercialised society, with market

\footnotetext{
${ }^{80}$ Crossman, Poverty, pp. 112-113.

${ }^{81}$ Crossman, 'Welfare regimes under the Irish Poor Law 1850-1921', UK Data Archive.

${ }^{82}$ Age heaping patterns may sometimes be the result of intentional misreporting if a society's institutions incentivise such behaviour. One such case is Ireland in the early-twentieth century, when exaggerating ages had a clear financial reward with the introduction of the Old Age Pension for those aged 70 and over in 1908 (Lee, 'Irish agriculture', p. 73; Budd and Guinnane, 'Intentional age-misreporting').

${ }^{83}$ The distinction between the supply of, and demand for, literacy in nineteenth-century Britain is discussed in Mitch, Rise of popular literacy.
} 
interactions becoming commonplace and rent to landlords or middlemen paid bi-annually. ${ }^{84}$ The poorest segments of the population were served by 'microcredit' providers who issued loans and required regular repayments. ${ }^{85}$ High levels of age heaping were present despite this commercialisation, and so the act of heaping may mean something more than basic numeracy. Ireland was a society where passports were not required for travel and where there was no compulsory registration of births, deaths and marriages until 1864. Birth rates were high, which reduced the significance of life events as a means for parents to accurately recall their ages. The presence of heaping may therefore indicate either an inability or apathy towards the measurement or keeping of time. Perhaps age heaping can be seen as a broader indicator of the awareness of time, or is a reflection of prevailing religious mores, ${ }^{86}$ either of which may have affected efficiency and work intensity.

The 1841 census collected information on ages, monthly until the age of one and yearly thereafter, and published these data fully aware of the 'defects, as well as advantages'. In fact, the act of rounding in census returns was a phenomenon noted by census commissioners themselves: 'our ages $[\ldots]$ exhibited very plainly the enormous increase in the decimal years [...] and a very considerable augmentation also at the 5th years' ${ }^{87}$ The commissioners had two hypotheses why such age patterns existed: either there was a 'desire for fictitious youth' - underreporting ages to appear younger - or there was a certain convenience in rounding. They suggested that: ${ }^{88}$

[T]he tendency to speak in round numbers was even greater than the desire for fictitious youth, and that as many of the persons at the ages of 28 and 29 must have called themselves 30, as of those who were 31 and 32. [...] [B]ut to whatever causes these excesses of the 5th and 10th years are to be attributed, they are remarkably consistent [...]. It will not, however, be understood, that these returns can for a moment be placed in competition with information by regular registers of births and deaths; on the contrary, they are palpable evidence of the want of such registers.

An earlier generation of Irish economic historians also addressed the issue of heaped age statements from the 1841 census in relation to the effect it had on determining the age of marriage.

\footnotetext{
${ }^{84}$ Kling, Phaneuf and Zhao ('From Exxon to BP', p. 12) use behavioural economics to explain that rational-looking market outcomes may be the result of repeated interaction rather than due to some intrinsic characteristic of the individuals involved, such as their human capital.

${ }^{85}$ Hollis and Sweetman, 'Microcredit'; McLaughlin, 'An experiment'.

${ }^{86}$ In the spirit of Weber, Protestant ethic. Lee, Modernisation of Irish society, recounts an anecdote illustrating a possible Catholic concept of time: when questioned by an English visitor about a leaking roof, a Donegal man said 'there will be no drips in heaven' (p. 16).

${ }^{87}$ Report of the commissioners, p. xlvi.

${ }^{88}$ Ibid.
} 
Drake, writing in The Economic History Review in 1963, noted the tendency of ages to be expressed in frequencies of five and ten, and calculated that males were often older than their wives by as much as ten years. ${ }^{89}$ However, in a later response, Lee, highlighting what contemporary census commissioners found, argued that ages were as likely to be over- as under-estimated. ${ }^{90}$ While these twentieth-century demographers discussed age heaping only as a problem in the data that needed to be corrected, their nineteenth-century counterparts hypothesised - but themselves rejected - a link between age heaping and education, predating modern-day economic historians by over 150 years. ${ }^{91}$

Subsequent censuses did not report age distributions by year at county-level; instead ages were reported at quinquennial intervals, although yearly ages were reported at an aggregated provinciallevel. The exception to this was the 1871 census, the use of which enables us to make comparisons between the two populations over time. The 1871 census did not contain a similar discussion on the age distribution of the population; instead the census report focused on comparing 1871 to 1861 and with Britain's age distributions. ${ }^{92}$ The census commissioners used these age statements to make inferences about population declines and emigration following the Famine period in the 1840s. The procedure for the 1871 census was for census enumerators to leave a 'Form A', which recorded information about the family - such as age, occupation, number of residents - for every family in each house, before the 1st of April. The enumerator would then fill out a 'Form B', a separate form relating to the quality of the house. The enumerator was to return to the house and collect Form A and 'see that each column in the Form is properly filled; if it is not, he is then to obtain the necessary information, and fill it himself ${ }^{93}$

\section{[Figures 1-3 about here]}

Figure 1 illustrates the age distribution of 23-72 year-olds in the 1841 and 1871 censuses. A similar pattern of heaping at rounded ages occurs in both censuses, for males and females. Figure 2 plots the distribution of ages of Clonmel Gaol's prisoners and Thurles Workhouse's inmates as recorded in the prison registers and admittance records, while figure 3 is a histogram of prisoners' and inmates' years of birth implied from these sources. Age heaping is clearly present in the data, both for

\footnotetext{
${ }^{89}$ Drake, 'Marriage and population'.

${ }^{90}$ Lee, 'Marriage and population'.

${ }^{91}$ Report of the commissioners, p. xlvi. Officials apparently rejected the age heaping-education link because they argued that heaping was visible in data for Mayo, a rural county 'the lowest in the scale of education', and Dublin, where schooling was more widespread. What officials apparently failed to do was to examine the degree to which heaping occurred in both places, and do so by birth cohort.

${ }^{92}$ Census of Ireland, 1871 , pp. 48-52.

${ }^{93}$ Ibid., pp. 489-490.
} 
women and men, and reflects the heaping pattern in the Tipperary census data; however heaping is more prevalent in the female prison and workhouse data than in the female census data.

Nineteenth-century Irish census officials argued that 'decimal and 5th year augmentation' (i.e. age heaping) followed a 'constant law', which made interpolating 'true' age tables possible; they provided corrected estimates in an appendix to the 1841 report. ${ }^{94}$ Essentially, they were doing what statisticians do with such data today: the United Nations uses the Whipple Index (WI) to detect the incidence of age heaping, and thus to assess the quality of its age data. ${ }^{95}$ The WI is a ratio of the share of people reporting an age ending zero or five to all age statements, and is obtained as follows:

$$
W I=\left(\frac{n_{25}+n_{30}+\cdots+n_{65}+n_{70}}{1 / 5 \times\left(n_{23}+n_{24}+n_{25}+\cdots+n_{72}\right)}\right) \times 100 \text { if } W I \geq 100 ; \text { else } W I=100
$$

A value of 500 indicates that all age statements end in zero or five; a value of 100 indicates no heaping. A'Hearn, Baten and Crayen, on the suggestion of Gregory Clark, modify WI to range between zero and 100, where zero indicates that everyone rounds, and 100 that no one does. ${ }^{96}$ This modified index, known as the ABCC index, is argued to be interpretable as the share of the population that is numerate, and is given as follows: ${ }^{97}$

$$
A B C C=\left(1-\frac{(W I-100)}{400}\right) \times 100, \text { if } W I \geq 100 ; \text { else } A B C C=100
$$

\section{IV: Representativeness and selection}

A large body of anthropometric evidence suggests that data based on convicts do not reflect the overall population. Building on the work of Becker, ${ }^{98}$ the rationale behind this bias is that individuals with low opportunity costs select themselves more easily into crime, and therefore into prison samples. Persico, Postlewaite and Silverman find that taller workers receive a wage premium, with the disparity in wages being similar in magnitude to the race and gender gaps. ${ }^{99}$ Similarly, Case and Paxson find that individual height reflects superior intellectual capabilities, and that the latter explain

\footnotetext{
${ }^{94}$ Report of the commissioners, pp. 1xxii-lxxiii.

${ }^{95}$ United Nations, Demographic yearbook, p. 5, 133.

${ }^{96}$ A'Hearn, Baten and Crayen, 'Quantifying quantitative literacy'.

${ }^{97}$ Given the formula, ABCC values above 100 are technically possible, and should be interpreted as $100 \%$ numeracy. We adopt the ABCC measure throughout the ensuing analysis in order to make our results comparable with the extant literature.

${ }^{98}$ Becker, 'Crime and punishment'.

${ }^{99}$ Persico, Postlewaite and Silverman, 'The effect of adolescent experience'.
} 
a large portion of the height premium paid in labour markets. ${ }^{100}$ In other words: short individuals and individuals with inferior human capital are disadvantaged in official labour markets, while for taller individuals the opposite is true. In this regard, Bodenhorn, Moehling and Price find that individual stature is negatively correlated with age at entry into criminal activity. ${ }^{101}$ In summary, prison populations probably yield a downwardly biased height estimate if taken as a benchmark for the overall population. $^{102}$

Given the relationship between height and human capital, it is no stretch to posit that prison populations' age heaping patterns may be no more representative than their anthropometry; it is unlikely that prison data accurately reflect the basic numeracy skills of a society's general population because the upper and middle social classes are underrepresented. ${ }^{103}$ The same can be said for the workhouses, where the lower strata of society are overrepresented. Our strategy is to correct the female prison and workhouse bias by identifying the corresponding male bias and using these to adjust female census numeracy estimates. We estimate a measure of societal human capital that is influenced neither by the FVV bias, nor the prison and workhouse-related selection biases. This is the essence of our difference-in-difference approach. We run a set of logistic regressions in order to investigate correlates of numeracy, which is approximated by the tendency to report a non-rounded age; the dependent variable equals 1 if an individual reports a non-rounded age (i.e. is 'numerate'), and 0 if a multiple of 0 or 5 is reported (i.e. is 'innumerate'). ${ }^{104} \mathrm{We}$ use prisoners' characteristics, summarized in table 1 , as explanatory variables: time of imprisonment, type of criminal offence, ${ }^{105}$ recidivism status, religious denomination, literacy status, place of origin, occupational status, ${ }^{106}$ and marital status serve as control variables, whereas binary variables capturing the decade of birth serve as the basis for estimating numeracy across birth cohorts. ${ }^{107}$ These variables are necessary since prisoners undergo selection, and this selection may vary over time (see figures 4 and 5).

\footnotetext{
${ }^{100}$ Case and Paxson, 'Stature and status'.

${ }^{101}$ Bodenhorn, Moehling and Price, 'Short criminals'.

${ }^{102}$ Moreover, the size of this downward bias may vary across time, an issue that Bodenhorn, Guinnane and Mroz highlight in a recent working paper ('Caveat lector').

103 Our method relies on the assumption that male and female prison or workhouse inmates underwent similar selection mechanisms.

${ }^{104}$ In line with the original WI, the dataset used in all regression analysis includes only individuals whose stated age is between 23 and 72 .

${ }^{105}$ Categorised by adapting the official contemporary classification (Judicial statistics).

${ }^{106}$ Classified using the Armstrong scale (Armstrong, 'The use of information').

107 Our econometric methodology is similar to Baten and Fourie, 'Numeracy of Africans', who use court records to ascertain the numeracy of different populations residing in the Cape Colony.
} 


\section{[Figures 4 and 5 about here]}

As discussed in section II, Irish prisoners were likely to be (more) positively selected during the Great Famine since some individuals apparently committed offences in order to gain access to allegedly superior prison nutrition. The results presented in table 2 support this view; individuals convicted during the 1840 s were more likely to report a non-rounded age than prisoners of subsequent periods. A dichotomous variable controlling for those aged 23 to 32 helps to control for the phenomenon that this age group is better at reporting a correct age due to their proximity to birth, marriage, and military service. ${ }^{108}$ Another dichotomous variable identifying recidivists controls for their potential selection and their multiple appearance in the analysis. ${ }^{109}$

\section{[Tables 1, 2, 3 and 4 about here]}

In a second step we use the odds ratios presented in table 2 to compute marginal effects of each of the birth cohort coefficients and adjust those according to the methodology suggested by Juif and Baten. ${ }^{110}$ We repeat this process with workhouse data, the results of which are reported in tables 3 and 4. These adjusted marginal effects constitute an alternative computation of conventional ABCC values which offers the possibility to control for unrelated effects, therefore creating less biased time trends in numeracy (table 5). Finally, in order to calculate the magnitude of the FVV bias, we apply a difference-in-difference approach: assuming that male age heaping patterns - both in the census and the prison and workhouse data - are actually reported by males themselves, we compare numeracy scores of the male census, and prison and workhouse populations. In a subsequent step we use the estimated magnitude of this bias to adjust the numeracy of female prison and workhouse inmates to estimate female numeracy that is biased neither by prison or workhouse selection, nor male household heads. ${ }^{111}$ Formula 3 indicates this approach:

\footnotetext{
${ }^{108}$ Following Crayen and Baten, 'Global trends'.

${ }^{109}$ Recidivists were identified by matching names across registers. This identification strategy likely over-estimates the number of recidivists due to similarity in names.

${ }^{110}$ A correction of these coefficients is necessary since approximately $20 \%$ of all age statements that are allegedly 'rounded' are in fact accurate. To obtain a corrected numeracy coefficient, they suggest that marginal effects are multiplied by the factor 1.25 (Juif and Baten, 'On the human capital', online appendix).

111 The patriarchal nature of Irish society ensured that men were household heads in the overwhelming majority of cases where a male was present. Migration patterns do not distort this generalisation as the Irish emigrated as young males and females rather than as older heads of household or entire households (e.g. see Akenson, The Irish diaspora). Even if for whatever reason women were in some minority of cases household heads, the fact that we do not know in what proportion renders female numeracy estimates from census age heaping patterns anyway unreliable.
} 


$$
A B C C_{f c t}=A B C C_{f p t}+\left(A B C C_{m c t}-A B C C_{m p t}\right)+\Delta_{t}
$$

$\mathrm{ABCC}_{f c t}$ indicates female numeracy levels calculated from census age statements at time $t$, a cohort's decade of birth. These ABCC values are compared with the numeric abilities of the corresponding female prison or workhouse population $\left(\mathrm{ABCC}_{f p t}\right)$. These have to be corrected by adding the prison or workhouse bias, which is estimated by computing the difference between male census and prison and workhouse populations. $\Delta_{t}$ indicates the unexplained rest, that is the part of numeric ability of the female census population which may help to shed light on potential biases related to male household heads reporting their spouses' ages - the FVV bias. If female age statements are unaffected by aforementioned biases, $\Delta_{t}$ is expected to be small. Formula 4 presents the test scheme; table 6 reports our findings.

$$
\Delta_{t}=\left(A B C C_{f c t}-A B C C_{f p t}\right)-\left(A B C C_{m c t}-A B C C_{m p t}\right)
$$

\section{V: Results and robustness}

Results indicate that the numeric abilities of both males and females from Tipperary whose ages were reported during the 1841 census were generally increasing between birth cohorts (figure 6). We observe a similar trend for ages reported in the 1871 census. However, a comparison of ABCC values between censuses does not reveal an overall long-run increase in numeracy but rather stagnating scores. There is even a difference in ABCC values of the 1810s birth cohorts in the two censuses. Theoretically, this cohort should report the same degree of heaping in both censuses since numeracy skills are not expected to decrease over time; they tend to be acquired in early life. The substantial internal and external migration and excess mortality associated with the Great Famine period (18451852) possibly resulted, on average, in a somewhat lower skilled population in 1871 compared with the Pre-Famine population; while the trend remained upward, there was a downward shift in levels. ${ }^{112}$

Logistic regression models using the prison data, explaining the probability to report a nonrounded age, suggest that Protestants, literates and recidivists tend to report their ages more accurately than our reference category (table 2). Moreover, individuals who had migrated to Tipperary heaped more than locals. We control for individuals aged 23 to 32 and those individuals who were convicted during the Famine and our results confirm aforementioned hypotheses; both groups tend to report ages more accurately. We find little evidence of differences between occupational groups with regard to age heaping; only for professions related to agriculture do we find a statistically significant negative

\footnotetext{
${ }^{112} \mathrm{We}$ observe a u-shaped pattern in both censuses, where younger and older generations are less likely to heap. We consider this to be either a reflection of selective mortality rates, or a societal reverence for the elderly (Budd and Guinnane, 'Intentional age-misreporting').
} 
coefficient. Figure 5 (offences) suggests that the composition of the prison population changed over time. We address this potential bias by controlling for different types of crime, with offences against property without violence (e.g. larceny) serving as a consistent reference category. As discussed in the previous section, we use odds ratios of birth decade-dummies and corresponding marginal effects in order to estimate $\mathrm{ABCC}$ values (table 5). ABCC scores of the prison population show a different development to those of the census population; levels during the late eighteenth century were low, but successive increases occurred during the following decades.

\section{[Tables 5 and 6 about here]}

We estimate another set of logistic regressions for the Thurles workhouse using data from Crossman. ${ }^{113}$ We estimate ABCC values of workhouse inmates in order to gain insights into the development of numeric abilities of this other societal group (summary statistics in table 3). Our models control for time of admission to workhouse, young age, and marital status. Regression results, presented in table 4, suggest that individuals aged between 23 and 32 tended to have higher numeric abilities than individuals at other ages. Moreover, we find that married females reported their ages more accurately than single women, while the opposite is true for married men. We do not find a difference in heaping patterns between single and widowed individuals.

Information on the quality of clothing at the time of admission is available for a sub-sample of workhouse inmates. Furthermore, we have information about the date and nature of release for some individuals. The overwhelming majority of individuals were released from the workhouse within one year of admission; however, approximately four per cent of inmates died while resident. Results suggest that there are no differences in numeracy between those individuals who entered the workhouse with 'bad' clothing and those with 'middle' or 'good' clothing. Conversely, male and female individuals who eventually died during their stay tended to state their ages less accurately than surviving inmates. ABCC trends for male and female Tipperary workhouse populations are similar to trends of their corresponding prison populations. Numeracy levels implied by ABCC scores were low for this sample during the early nineteenth century, but increased by the mid-century. Differences in $\mathrm{ABCC}$ levels between these groups are more pronounced among males and females born between the 1840 s and 1880 s.

Overall differences in ABCC levels between males and females are visible throughout the period under analysis (see table 5), and suggest that males had superior numeracy skills than females for census, prison and workhouse samples. For the census populations, the ABCC advantage for males is approximately eight and 13 points for the 1770 s and 1780 s cohorts, and decreases to

\footnotetext{
${ }^{113}$ See description of data in Crossman, Poverty.
} 
approximately five to seven points between the 1790 s and 1810 s cohorts. As for prison inmates, gender differences are more pronounced: male prisoners have an $\mathrm{ABCC}$ advantage of approximately 29 and 43 for the 1780s and 1790s cohorts; this value decreased in subsequent periods, falling from approximately 25 to 11 between the 1800s and the 1840s. We find no ABCC difference between males and females born in the 1850s; and a female advantage of eight ABCC points for the 1860s. In general, we find similar evidence to suggest that males were more numerate than their female counterparts for the Tipperary workhouse population.

Table 6 provides several estimations of $\Delta_{t}$, the unexplained difference between female numeric abilities based on census records, and prison and workhouse registers. If we use male and female prison scores, the result of the computation according to formula 4 suggests that the unexplained part of female numeracy accounts for $26 \mathrm{ABCC}$ points on mean, and 25 on median. We obtain a mean $\Delta_{t}$ value of 11 , and a median of 13 , for workhouse inmates using the 1871 census as a reference. ${ }^{114}$ These results confirm the presence of an FVV bias in Ireland's census returns, and indicate that female numeracy based on Irish census data overestimates numeracy on average.

\section{[Figures 6, 7 and 8 about here]}

One way to translate the size of our $\Delta_{t}$ values into economically meaningful magnitudes is to compare them with the time it took for the observed populations' numeracy scores to improve by the same amount. For example, between the 1790s to 1820s cohorts, the ABCC score of Clonmel's female inmates increased from approximately 21 to 45; this increase of 24 ABCC points, which took 30 years to achieve, corresponds to the size of the female census bias. In other words, if there is an undetected bias in female census numeracy, then scholars are systematically overestimating numeracy levels and underestimating any improvements in numerical ability by 30 years of human capital development; the FVV bias can be large and important.

We are able to identify sub-groups of prisoners, allowing a series of robustness checks. We run a test similar to the aforementioned procedure using those individuals convicted for offences related to drunkenness, which was criminalized in Ireland only in the mid-1870s. ${ }^{115}$ The 1871 criminal justice

\footnotetext{
${ }^{114}$ Note that not all $\Delta_{t}$ values are positive: three out of 31 calculations are negative, but small in magnitude (see table 6). Our conjecture is that the earliest birth cohort in the workhouse suffers from aforementioned selective mortality effects.

115 Prisoners held for drunkenness enter Clonmel Gaol for the first time in the mid-1870s. This coincides with the introduction of the Licensing Acts, 1872 and 1874 (National Crime Council, Public order offences, p. 13). Section 25 of the 1874 Licensing Act (Ireland) stated that 'every person who, in any highway or other public place, whether a building or not, is so drunk as to be incapable of taking care of himself, may be detained by any constable until he can, with safety to himself, be discharged, but if so detained he shall be summoned in due course to answer for such offence, and he shall not by such discharge be relieved from the liability to any penalty to which he is subject'.
} 
statistics state that the increase in convictions for drunkenness and other nuisances was not due to an increase in those crimes 'but from a more active and vigilant enforcement of the law'. ${ }^{116}$ The rationale behind the use of drunks is that this sub-sample of convicts underwent a less strict selection and, hence, reflects numeracy closer to 'true' numeracy. ${ }^{117}$ Economically speaking, we address Bodenhorn et al.'s concerns regarding representativeness by only taking into account individuals who are less characterized by low opportunity costs of crime, but instead attracted the authorities' attention by drinking. ${ }^{118}$ We expect that this sub-sample of convicts also underwent some sort of selection, but that this selection was less severe compared to the whole prison population, enabling us to estimate $\Delta_{t}$ values more accurately. Similarly, we are able to identify political prisoners, who may offer insights into a potentially more educated group's numeracy.

The results of these exercises, reported in figure 7 and tables 5 and 6, confirm our expectations in terms of selection, and confirm our findings on the size and sign of $\Delta_{t}$. Generally, the numeracy of drunkards tends to be at least equal to, but often higher than, numeracy in the whole prison population. ${ }^{119}$ Male political prisoners' numeracy was on a similar footing to numeracy in the full male prison population. Conversely, female political prisoners generally exhibit ABCC values below female prisoners. Applying our difference-in-difference approach increases the $\Delta_{t}$ value for the $1810 \mathrm{~s}$ from 30 to 66 for drunkards, but decreases to -2.6 for political prisoners.

The censuses that underlie our county-level estimates of numeracy were taken in 1841 and 1871 , before and after the massive mortality and emigration shock that accompanied the Great Famine. Meanwhile, the prison registers that we use to correct these numeracy estimates refer to people incarcerated throughout the nineteenth century, including cohorts where a considerable portion of Ireland's inhabitants had either died or left. For example, a person born in 1820 who is imprisoned in 1840 may have different characteristics to a prisoner who is also born in 1820 but incarcerated in 1860; the latter is not just older but the Famine epoch may have further selection effects. ${ }^{120}$ We partly take this feature into account by controlling for the time of imprisonment in the logistic regressions; respective coefficients are supposed to capture at least some of this effect.

\footnotetext{
${ }^{116}$ Criminal and judicial statistics, 1871, p. 28.

117 The logic follows from Riggs, 'Standard of living', p. 94, a paper that argues that the study of Scottish prisoners is representative of the general population because Scotland was a society of heavy drinkers and many were at risk of arrest.

${ }^{118}$ Bodenhorn, Guinnane and Mroz, 'Caveat lector'.

${ }^{119}$ An exception seems to be Tipperary birth cohorts of the 1820 s to the 1850 s, where drunken females heap more (are less numerate) than the average female prison population.

${ }^{120}$ We find that Tipperary's 1871 census is on average more heaped than its 1841 census. This pattern is also evident in Mokyr and Ó Gráda, 'Emigration and poverty', p. 376, who find, at the national level, that the 1851 census was more heaped than that of 1841 .
} 
As discussed, Mokyr suggests those that left Ireland were less numerate than those that stayed behind, while Fitzpatrick argues that individuals who did not migrate instead had more invested in their human capital. In short, a possible selection issue arises from the use of the 1841 census and prison and workhouse inmates incarcerated before the Famine. We take these considerations into account by using another sub-group of our prisons: using only those individuals who were imprisoned after 1870 yields a sample that can be compared directly with the census population of 1871 . ABCC trends of these groups are presented in table 6 and figure 8 .

In order to investigate further the migration selection problem, we compare the numeracy of Irish emigrants to England and Wales from County Tipperary with census and prison populations in figure $8 .{ }^{121}$ The census used for emigrants refers to a Post-Famine year, namely 1881. In contrast to Mokyr's findings for migrants to the US, our own comparison suggests that emigrants were more numerate than those that stayed behind. Numeracy of male migrants from Tipperary to England and Wales was 29 ABCC points higher than the corresponding census populations in the $1810 \mathrm{~s}$ and $1820 \mathrm{~s}$, which subsequently decreases to 19 and eight in the 1830s and 1840s. For female migrants this difference was 32 and $30 \mathrm{ABCC}$ points for the 1810s and 1820s, and 25 and six points for the 1830s and 1840s. Generally, Irish migrants to England and Wales between the 1810s and 1850s show numeracy values of 81 to $86 \mathrm{ABCC}$ points. ${ }^{122}$

\section{VI: Conclusion}

This article provides a long span of numeracy estimates for a rural area of the island of Ireland. ${ }^{123} \mathrm{We}$ find trends of increasing numeracy that correspond to the growth in national schooling. This, we believe, lends support to the Geary and Stark view of TFP-driven productivity growth in the PostFamine period. ${ }^{124}$ Our findings are consistent with the view that emigration was not the sole driver of Irish economic performance in this period. ${ }^{125}$ Improvements in numeracy are particularly pronounced in the case of women, who started out in the nineteenth century with very low levels. The time it took to close the education gap between Ireland's women and men is astonishing, given the size of women's initial disadvantage. The human capital accumulation of women should therefore be

\footnotetext{
${ }^{121} \mathrm{ABCC}$ estimates for Irish emigrants to England and Wales are calculated using data from the 1881 census described in Day, 'Leaving home'.

${ }^{122}$ As a comparison, corresponding English and Welsh populations had numeracy values in the order of 94 to 98 ABCC points (Friesen, Baten and Prayon, 'Women count').

${ }^{123}$ An online appendix extends our results to include a more urban part of the island.

${ }^{124}$ Geary and Stark, 'Examining', pp. 931-932.

${ }^{125}$ Geary and Stark, 'Regional GDP', p. 15, estimate that only between 19 and 32\% of labour productivity growth was due to emigration.
} 
considered a potentially important source of Ireland's convergence, not just by means of their direct contribution to the labour force, but also through their education of future generations. We find mixed evidence among our samples for Mokyr's argument that emigrants were less numerate than those they left behind; while emigrants heaped less, there was a downward shift in the overall level of numeracy for the 1810 birth cohort between 1841 and $1871 .^{126}$ We do find support for Fitzpatrick's argument that those Irish women who failed to escape the island sought instead to better themselves through education. $^{127}$

FVV argue that there is a problem in census-derived age heaping estimates for women because male household heads report their age on their behalf. If males are generally more numerate, as they argue, this could systematically bias female numeracy estimates upwards. They advocate instead to only measure age heaping patterns of unmarried women, a solution which itself introduces a selection bias. We offer a very different solution: we estimate the influence of this potential bias by comparing ABCC trends based on the census, and prison and workhouse registers, the last two of which contain self-reported age statements. The estimated bias for County Tipperary is generally positive, with mean average deviation between census and prison and workhouse estimates of female numeracy of 26 ABCC points. ${ }^{128}$ We therefore find independent evidence of the FVV bias and recommend that female age heaping estimates should be used with caution for patriarchal societies where the census is the only available source. ${ }^{129}$

In the absence of perfectly representative demographic data, historians of Ireland must engage in "informed speculation" using alternative sources. The empirical analysis performed in this study suggests that prison and workhouse registers are valuable sources of quantitative social information and should not be discarded by social science historians. Prison data allow detailed analyses of all societal groups, including by type of offender and by level of sophistication of an individual's occupation. They are also recorded on a daily basis, allowing more precise analyses than decadallycompiled census data. Contrary to expectations, we do not find that prison populations constitute the lowest end of society in terms of their human capital; a comparison of prison and workhouse samples

\footnotetext{
${ }^{126}$ Mokyr, Why Ireland starved, pp. 244-46.

${ }^{127}$ Fitzpatrick, "“A share of the honeycomb", p. 219.

${ }^{128}$ Our finding of positive $\Delta_{t}$ values, regardless of the sample used, is consistent with the assumption of similar selection by gender into prisons and workhouses. Note that we find similar results using other prison registers located elsewhere in Ireland. These results are reported and contextualised in the appendix.

${ }^{129}$ Our results contrast markedly with analysis of numeracy levels in the Low Countries, where De Moor and Van Zanden ("“Every woman counts") use some individual-level age data pertaining mostly to urbanized areas to find that the gender gap was already eliminated there by 1600 . This suggests that our methodological recommendations may be most important for the study of rural and peripheral areas of Europe, and least important for urbanized and developed ones.
} 
reveals that it was the latter population that probably had lower levels of numeracy. Future scholars may seek out more and better demographic sources to address the issues that are raised in this study. Further quantification of Irish economic history can only foster a greater understanding of Ireland's economic past. 


\section{Footnote references}

A'Hearn, B., Baten, J. and Crayen, D., 'Quantifying quantitative literacy: age heaping and the history of human capital', The Journal of Economic History, 69 (2009), pp. 783-808.

Akenson, D. H., The Irish education experiment: the national system of education in nineteenth century Ireland (London, 1970).

Akenson, D. H., The Irish diaspora: a primer (Belfast, 1993).

Armstrong, W. A., 'The use of information about occupation', in E. A. Wrigley, ed., Nineteenthcentury society: essays in the use of quantitative methods for the study of social data (Cambridge, 1972), pp. 191-310.

Barro, R. J. and Lee, J. W., 'A new data set of educational attainment in the world, 1950-2010', Journal of Development Economics, 104 (2013), pp. 184-198.

Baten, J. and Fourie, J., 'Numeracy of Africans, Asians, and Europeans during the Early Modern Period: new evidence from Cape Colony court registers', Economic History Review, 68 (2015), pp. 632-656.

Baten, J. and Sohn, K., 'Back to the 'normal' level of human-capital driven growth? A note on early numeracy in Korea, China and Japan, 1550 - 1800' (University of Tübingen Working Papers in Economics and Finance, No. 52, 2013).

Beames, M. R., 'Rural conflict in pre-famine Ireland: peasant assassinations in Tipperary 1837-1847', Past and Present, 81 (1978), pp. 75-91.

Becker, G. S., 'Crime and punishment: an economic approach', The Journal of Political Economy, 76 (1968), pp. 169-217.

Becker, G. S., 'A theory of marriage: part I', The Journal of Political Economy, 81 (1973), pp. 813846.

Begley, J., Geary, F. and Start, T., 'Convergence in the pre-1911 Atlantic economy: what really happened to wages in Ireland between 1881 and 1911?', Cambridge Journal of Economics, advance access (December 2014).

Breton, T., 'Schooling and national income: how large are the externalities?', Education Economics, 18 (2010), pp. 67-92

Breton, T., 'Schooling and national income: how large are the externalities? Corrected estimates', Education Economics, 18 (2010), pp. 455-456.

Black, R. D. C., Economic thought and the Irish question, 1817-1870 (Cambridge, 1960).

Bodenhorn, H., Moehling, C. M. and Price, G., 'Short criminals: stature and crime in early America', Journal of Law and Economics, 55 (2012), pp. 393-419. 
Bodenhorn, H., Guinnane T. W. and Mroz, T. A., 'Caveat lector: sample selection in historical heights and the interpretation of early industrializing economies' (NBER Working Papers, no. 19955, March 2014).

Boulier, B. L. and Rosenzweig, M. R., 'Schooling, search and spouse selection: testing economic theories of marriage and household behavior', The Journal of Political Economy, 92 (1984), pp. 712-732.

Budd, J. W. and Guinnane, T. W., 'Intentional age-misreporting, age-heaping, and the 1908 Old Age Pensions Act in Ireland', Population Studies, 45 (1991), pp. 497-518.

Burke, W. P. History of Clonmel (Waterford, 1907).

Carroll-Burke, P., Colonial discipline: the making of the Irish convict system (Dublin, 2000).

Case, A. and Paxson, C., 'Stature and status: height, ability, and labor market outcomes', The Journal of Political Economy, 116 (2008), pp. 499-532.

Choi, S. M. 'How large are learning externalities?' International Economic Review, 52 (2011), pp. 1077-1103.

Clarke, P., 'The teaching of bookkeeping in nineteenth-century Ireland', Accounting, Business \& Financial History, 18 (2008), pp. 21-33.

Coolahan, J., Irish education: its history and structure 1800-1980 (Dublin, 1981).

Cox, C., Negotiating insanity in the southeast of Ireland, 1820-1900 (Manchester, 2012).

Cooke, P., A history of Kilmainham Gaol, 1796-1924 (Dublin, 1995).

Crafts, N. F. R., 'Exogenous or endogenous growth? The Industrial Revolution reconsidered', The Journal of Economic History, 55 (1995), pp. 745-772.

Crayen, D. and Baten, J., 'Global trends in numeracy 1820-1949 and its implications for long-termgrowth', Explorations in Economic History, 47 (2010), pp. 82-99.

Crossman, V., Politics, pauperism and power in late nineteenth-century Ireland (Manchester, 2006).

Crossman, V., Poverty and the Poor Law in Ireland 1850-1914 (Liverpool, 2013).

Crowley, J., Smith, W. J. and Murphy, M., Atlas of the Great Irish Famine, 1845-1852 (Cork, 2012).

Dalmazzo, A. and de Blasio, G. 'Production and consumption externalities of human capital: an empirical study for Italy', Journal of Population Economics, 20 (2007), pp. 359-382.

Day, J., 'Leaving home and migrating in 19th century England and Wales: new evidence from the 1881 census' (unpublished $\mathrm{PhD}$ thesis, University of Cambridge, 2013).

De Moor, T. and Van Zanden, J. L., "Every woman counts": a gender-analysis of numeracy in the Low Countries during the Early Modern Period', Journal of Interdisciplinary History, 41 (2010), pp. 179-208. 
De Moor, T. and Zuijderduijn, J., 'The art of counting: reconstructing numeracy of the middle and upper classes on the basis of portraits in the early modern Low Countries', Historical Methods, 46 (2013), pp. 41-56.

Drake, M. 'Marriage and population growth in Ireland, 1750-1845', The Economic History Review, 16 (1963), pp. 301-313.

Fafchamps, M. and Quisumbing, A., 'Assets at marriage in rural Ethiopia', Journal of Development Economics, 77 (2005), pp. 1-25.

FitzGerald, G., Irish primary education in the early nineteenth century (Dublin, 2013).

Fitzpatrick, D., “"A share of the honeycomb”: education, emigration and Irishwomen', Continuity and Change, 1 (1986), pp. 217-234.

Fitzpatrick, D., 'Emigration, 1801-70', in W. E. Vaughan (ed.) A new history of Ireland, v: Ireland under the Union, i, 1801-70 (Oxford, 1989), pp. 562-622.

Földvári, P., van Leeuwen, B. and van Leeuwen-Li, J., 'How did women count? A note on gender specific age heaping differences in the 16th-19th century', The Economic History Review, 65 (2012), pp. 304-313.

Friesen, J., Baten, J. and Prayon, V., 'Women count. Gender (in-)equalities in the human capital development in Asia, 1900-60' (University of Tübingen Working Papers in Economics and Finance, no. 29, 2012).

Galor, O., Unified growth theory (New Jersey, 2011).

Geary, F., 'Regional industrial structure and labour force decline in Ireland between 1841 and 1851', Irish Historical Studies, 30 (1996), pp. 167-194.

Geary, F. and Stark, T., 'Examining Ireland's Post-Famine economic growth performance', The Economic Journal, 112 (2002), pp. 919-935.

Geary, F. and Stark, T., 'Regional GDP in the UK, 1861-1911: new estimates', The Economic History Review, 68 (2015), pp. 123-144.

Gray, P., The making of the Irish poor law, 1815-43 (Manchester, 2009).

Hall, J. C., 'Positive externalities and government involvement in education', Journal of Private Enterprise, 22 (2006), pp. 165-175.

Hatton, T. J. and Williamson, J. G., 'After the Famine: emigration from Ireland, 1850-1913', The Journal of Economic History, 53 (1993), pp. 575-600.

Hippe, R., 'How to measure human capital? The relationship between numeracy and literacy', Economies et Sociétés, 46 (2012), pp. 1627-1654.

Hollis, A. and Sweetman, A., 'Microcredit: what can we learn from the past?', World Development, 26 (1998), pp. 1875-1891. 
Jordan, D., Land and popular politics in Ireland: county Mayo from the Plantation to the Land War (Cambridge, 1994).

Juif, D.-T. and Baten, J., 'On the human capital of Inca Indios before and after the Spanish Conquest. Was there a "Pre-Colonial Legacy"?', Explorations in Economic History, 50 (2013), pp. 227241.

Kavanagh, C. and Doyle, E., 'Human capital and productivity in the Irish context', in Perspectives on Irish Productivity (Dublin, 2007), pp. 297-314.

Kennedy, K. A., Giblin T. and McHugh, D., The Economic development of Ireland in the twentieth century (London, 1988).

Klasen, S., 'Low schooling for girls, slower growth for all? Cross-country evidence on the effect of gender inequality in education on economic development', The World Bank Economic Review, 16 (2002), pp. 345-373.

Kling, C. L., Phaneuf, D. J. and Zhao, J., 'From Exxon to BP: has some number become better than no number?', Journal of Economic Perspectives, 26 (2012), pp. 3-26.

Krueger, A. B. and Lindhal, M., 'Education for growth: why and for whom?', Journal of Economic Literature, 39 (2001), pp. 1101-1136.

Lee, J., 'Marriage and population in Pre-Famine Ireland', The Economic History Review, 21 (1968), pp. 283-295.

Lee, J., 'Irish agriculture', Agricultural History Review, 17 (1969), pp. 64-76.

Lee, J., The modernisation of Irish Society 1848-1918 (1973, revised edition 2008).

Lindert, P., 'The rise of social spending, 1880-1930', Explorations in Economic History, 31 (1994), pp. 1-37.

Lindert, P., Growing public: social spending and economic growth since the eighteenth century, vol. 1 \& 2 (Cambridge, 2004).

Logan, J., 'Sufficient for their needs: literacy and elementary schooling in the nineteenth century', in M. Daly and D. Dickson (eds.), The origins of popular literacy in Ireland: language change and educational development 1700-1920 (Dublin, 1990), pp. 113-137.

Lucas, R. E., 'On the mechanics of economic development', Journal of Monetary Economics, 3 (1988), pp. 3-42.

Mankiw, G., Romer, D. and Weil, D. 'A contribution to the empirics of economic growth', Quarterly Journal of Economics, 107 (1992), pp. 407-437.

McConville, S., Irish political prisoners, 1848-1922: theatres of war (2003).

McDowell, R. B., The Irish administration 1801-1914 (1964).

McLaughlin, E., 'An experiment in banking the poor: the Irish Mont-de-Piété, c. 1830-1850', Financial History Review, 20 (2013), pp. 49-72. 
McLaughlin, E., 'Competing forms of cooperation? Land League, Land War and cooperation in Ireland, 1879 to 1914', Agricultural History Review, 63 (2015), pp. 81-112.

McMahon, R., Homicide in Pre-Famine and Famine Ireland (Liverpool, 2013).

McManus, A., The Irish hedge school and its book, 1695-1831 (Dublin, 2002).

Mitch, D. F., The rise of popular literacy in Victorian England: the influence of private choice and public policy (Philadelphia, 1992).

Mitchell, B. R., International historical statistics (London, 2008).

Mokyr, J., Why Ireland starved: a quantitative and analytical history of the Irish economy, 1800-1850 (2nd edition, 1985).

Mokyr, J. and Ó Gráda, C., 'Emigration and poverty in prefamine Ireland', Explorations in Economic History, 19 (1982), pp. 360-384.

Mokyr, J. and Ó Gráda, C., 'Poor and getting poorer? Living standards in Ireland before the Famine'. The Economic History Review, 41(1988), pp. 209-235.

Morrison, C. and Murtin, F., 'The century of education', Journal of Human Capital, 3 (2009), pp. 142.

National Crime Council, Public order offences in Ireland (Dublin, 2003).

Nicholls, G., A history of the Irish poor law in connexion with the condition of the people (1856).

O’Connor, J., The workhouses of Ireland: the fate of Ireland's poor (Dublin, 1995)

O’Donnell, S., Clonmel - 1840-1900: anatomy of an Irish town (Dublin, 2009).

Ó Gráda, C., 'A note on nineteenth-century Irish emigration statistics', Population Studies, 29 (1975), pp. 143-149.

Ó Gráda, C., 'Heights in Tipperary in the 1840s: evidence from prison registers', Irish Economic and Social History, 18 (1991), pp. 24-33.

Ó Gráda, C., A rocky road: the Irish economy since the 1920s (Manchester, 1997).

Ó Gráda, C., 'Savings banks as an institutional import: the case of nineteenth-century Ireland', Financial History Review, 10 (2003), pp. 31-55.

Ó Gráda, C., 'School attendance and literacy before the Famine: a simple baronial analysis', in G. FitzGerald, Irish primary education in the early nineteenth century (Dublin, 2013), pp.113131.

O’Shea, J., Prince of swindlers: John Sadlier M.P. 1813-1856 (Dublin, 1999).

Persico, N., Postlewaite, A. and Silverman, D., 'The effect of adolescent experience on labor market outcomes: the case of height', The Journal of Political Economy, 112 (2004), pp.1019-1053.

Riggs, P., 'The standard of living in Scotland, 1800-1850', in John Komlos (ed.), Stature, living standards, and economic development (Chicago, 1994), pp. 60-75. 
Stolz, Y., 'Essays on human capital formation, living standards and selective migration' (unpub. $\mathrm{PhD}$ thesis, Eberhard-Karls Universität Tübingen, 2012).

Stolz, Y and Baten, J., 'Brain drain in the age of mass migration: Does relative inequality explain migrant selectivity?', Explorations in Economic History, 49 (2012), pp. 205-220.

The Law Reform Commission (Ireland), Report on vagrancy and related offences (Dublin, 1985).

United Nations, 2004 demographic yearbook (56th edition, New York, 2007).

Weber, M., The Protestant ethic and the spirit of capitalism (1930).

\section{Official publications}

Report of the commissioners appointed to take the census of Ireland, for the year 1841, Appendix (P.P. 1843, XXIV).

Census of Ireland, 1851; Part VI, General report (P.P. 1851, XXXI).

Census of Ireland, 1861; Part V, General Report, Appendix, County Tables, Summary Index (P.P. 1863, LXI).

Census of Ireland, 1871. Part III. General report, with illustrative maps and diagrams, summary tables, and appendix (P.P. 1876, LXXXI).

Census of Ireland, 1881; Part V, General Report, Appendix, County Tables, Summary Index (P.P. 1882, LXXVI).

Census of Ireland, 1891; Part V, General Report, Appendix, County Tables, Summary Index (P.P. 1892, XC).

Census of Ireland 1901; Part II, General Report, with illustrative maps and diagrams, tables, and appendix (P.P.1902, CXXIX).

Census of Ireland 1911; General Report, with Tables and Appendix (P.P. 1912-13, CXVIII).

The twenty-eighth report of the Commissioners of National Education in Ireland (for the year 1861), with appendices, Vol. I. (P.P. 1862, XX).

The sixty-eighth report of the Commissioners of National Education in Ireland, year 1901 (P.P. 1902, XXX).

Judicial statistics, 1865. Ireland. Part I, Police - criminal proceedings - prisons (P.P. 1866, LXVIII).

Criminal and Judicial Statistics, 1871. Part I, Police - criminal proceedings - prisons (P.P. 1871, LXV).

Copy of rules and regulations in force in the prisons in Ireland (P.P. 1888, LXXXII). 
Table 1. Descriptive statistics (percentages), Clonmel Gaol prisoners, by gender

\begin{tabular}{|c|c|c|c|}
\hline & & $\begin{array}{c}\text { Females } \\
\text { (in \%) }\end{array}$ & $\begin{array}{l}\text { Males } \\
\text { (in \%) }\end{array}$ \\
\hline \multirow[t]{2}{*}{ Numeracy } & Numerate & 41 & 65 \\
\hline & Non-numerate & 59 & 35 \\
\hline \multirow{11}{*}{ Birth decade } & $1780 \mathrm{~s}$ & $<1$ & 1 \\
\hline & $1790 \mathrm{~s}$ & 2 & 2 \\
\hline & $1800 \mathrm{~s}$ & 6 & 4 \\
\hline & $1810 \mathrm{~s}$ & 15 & 8 \\
\hline & $1820 \mathrm{~s}$ & 28 & 13 \\
\hline & $1830 \mathrm{~s}$ & 24 & 12 \\
\hline & $1840 \mathrm{~s}$ & 18 & 16 \\
\hline & $1850 \mathrm{~s}$ & 6 & 14 \\
\hline & $1860 \mathrm{~s}$ & 1 & 17 \\
\hline & $1870 \mathrm{~s}$ & $<1$ & 11 \\
\hline & $1880 \mathrm{~s}$ & & 3 \\
\hline \multirow{8}{*}{$\begin{array}{l}\text { Time of } \\
\text { imprisonment }\end{array}$} & $1840 \mathrm{~s}$ & 11 & 8 \\
\hline & $1850 \mathrm{~s}$ & 32 & 14 \\
\hline & $1860 \mathrm{~s}$ & 24 & 9 \\
\hline & $1870 \mathrm{~s}$ & 21 & 12 \\
\hline & $1880 \mathrm{~s}$ & 12 & 14 \\
\hline & $1890 \mathrm{~s}$ & $<1$ & 23 \\
\hline & $1900 \mathrm{~s}$ & $<1$ & 20 \\
\hline & $1910 \mathrm{~s}$ & & 1 \\
\hline \multirow{9}{*}{ Offences } & Against the person & 14 & 23 \\
\hline & Property with violence & 3 & 3 \\
\hline & Property w/o violence & 29 & 16 \\
\hline & Begging and prostitution & 11 & 5 \\
\hline & Drunkenness & 7 & 32 \\
\hline & Indecency and public disorder & 16 & 8 \\
\hline & Treason & 10 & 9 \\
\hline & Rioting & 10 & 8 \\
\hline & Offence is unknown & 15 & 11 \\
\hline \multirow[t]{2}{*}{ Young age } & Aged 23-32 & 56 & 47 \\
\hline & Aged 33 and over & 44 & 53 \\
\hline \multirow[t]{2}{*}{ Recidivism } & Recidivist & 40 & 40 \\
\hline & One-time offender & 60 & 60 \\
\hline \multirow[t]{2}{*}{ Denomination } & Protestant & 3 & 2 \\
\hline & Catholic & 97 & 98 \\
\hline \multirow[t]{2}{*}{ Literacy } & Literate & 23 & 55 \\
\hline & Illiterate & 77 & 45 \\
\hline \multirow[t]{2}{*}{ Place of origin } & County Tipperary & 75 & 69 \\
\hline & Migrated to County Tipperary & 25 & 31 \\
\hline \multirow{5}{*}{ Occupational class } & Low & 14 & 43 \\
\hline & Medium & 3 & 15 \\
\hline & High & $<1$ & 1 \\
\hline & Farm related & $<1$ & 3 \\
\hline & Unknown & 83 & 38 \\
\hline \multirow[t]{4}{*}{ Marital status } & Single & $>1$ & 9 \\
\hline & Married & 2 & 6 \\
\hline & Widowed & & 1 \\
\hline & Unknown & 98 & 85 \\
\hline Number of prisoners & & 7,652 & 27,564 \\
\hline
\end{tabular}


Sources: Authors' calculations using all extant prison registers of Clonmel Gaol (1848-1849; 1849-1850; 1850-1851; $1851-1852 ; 1857-1862 ; 1862-1870 ; 1870-1878 ; 1878-1880 ; 1883-1893 ; 1894-1903 ; 1903-1925)$ held at the National Archive of Ireland, Dublin (Pris1).

Notes: Offences do not add to $100 \%$ because some prisoners are imprisoned for multiple offences. 
Table 2. Determinants of numeracy (odds ratios), Clonmel Gaol prisoners

\begin{tabular}{|c|c|c|c|c|c|c|c|c|c|c|}
\hline & \multicolumn{2}{|c|}{ Full sample } & \multicolumn{2}{|c|}{ Occupation known } & \multicolumn{2}{|c|}{ Drunkards only } & \multicolumn{2}{|c|}{ Political prisoners only } & \multicolumn{2}{|c|}{ Marital status known } \\
\hline & $\begin{array}{c}\text { Females } \\
\text { (1) }\end{array}$ & $\begin{array}{c}\text { Males } \\
\text { (2) }\end{array}$ & $\begin{array}{c}\text { Females } \\
\text { (3) }\end{array}$ & $\begin{array}{c}\text { Males } \\
\text { (4) }\end{array}$ & $\begin{array}{c}\text { Females } \\
\text { (5) }\end{array}$ & $\begin{array}{c}\text { Males } \\
\text { (6) }\end{array}$ & $\begin{array}{c}\text { Females } \\
\text { (7) }\end{array}$ & $\begin{array}{c}\text { Males } \\
\text { (8) }\end{array}$ & $\begin{array}{c}\text { Females } \\
\text { (9) }\end{array}$ & $\begin{array}{c}\text { Males } \\
\text { (10) }\end{array}$ \\
\hline \multicolumn{11}{|l|}{ Birth decade } \\
\hline 1780 & $\begin{array}{l}-0.59 * \\
(-1.66)\end{array}$ & $\begin{array}{c}-0.14 \\
(-0.77)\end{array}$ & & & & & & $\begin{array}{c}0.74 \\
(0.62)\end{array}$ & & \\
\hline 1790 & $\begin{array}{c}-1.60 * * * \\
(-7.26)\end{array}$ & $\begin{array}{c}-0.44 * * * \\
(-4.03)\end{array}$ & & & & & & $\begin{array}{c}-1.01 \\
(-1.53)\end{array}$ & & \\
\hline 1800 & $\begin{array}{c}-1.22 * * * \\
(-7.69)\end{array}$ & $\begin{array}{c}-0.73 * * * \\
(-8.35)\end{array}$ & $\begin{array}{c}-1.14 \\
(-1.06)\end{array}$ & $\begin{array}{c}0.47 \\
(0.77)\end{array}$ & $\begin{array}{c}-1.7 \\
(-1.53)\end{array}$ & $\begin{array}{c}0.23 \\
(0.32)\end{array}$ & $\begin{array}{c}0.8 \\
(1.08)\end{array}$ & $\begin{array}{c}-0.38 \\
(-0.91)\end{array}$ & & \\
\hline 1810 & $\begin{array}{c}-1.49 * * * \\
(-11.45)\end{array}$ & $\begin{array}{c}-0.65 * * * \\
(-9.18)\end{array}$ & $\begin{array}{c}0.03 \\
(0.04)\end{array}$ & $\begin{array}{c}0.52 * * * \\
(2.80)\end{array}$ & $\begin{array}{c}-1.38 \\
(-1.62)\end{array}$ & $\begin{array}{c}0.3 \\
(1.49)\end{array}$ & $\begin{array}{l}-1.03 * \\
(-1.89)\end{array}$ & $\begin{array}{c}0.03 \\
(0.10)\end{array}$ & $\begin{array}{c}1.5 \\
(1.25)\end{array}$ & \\
\hline 1820 & $\begin{array}{c}-0.54 * * * \\
(-5.79)\end{array}$ & $\begin{array}{c}-0.01 \\
(-0.22)\end{array}$ & $\begin{array}{c}0.13 \\
(0.53)\end{array}$ & $\begin{array}{c}0.08 \\
(0.82)\end{array}$ & $\begin{array}{c}-0.16 \\
(-0.51)\end{array}$ & $\begin{array}{c}-0.03 \\
(-0.21)\end{array}$ & $\begin{array}{c}-0.14 \\
(-0.48)\end{array}$ & $\begin{array}{l}0.35 * \\
(1.66)\end{array}$ & $\begin{array}{c}0.83 \\
(0.87)\end{array}$ & \\
\hline 1830 & reference & reference & reference & reference & reference & reference & reference & reference & reference & reference \\
\hline 1840 & $\begin{array}{c}0.37 * * * \\
(5.00)\end{array}$ & $\begin{array}{c}0.21 * * * \\
(4.27)\end{array}$ & $\begin{array}{c}1.16^{* * * *} \\
(6.78)\end{array}$ & $\begin{array}{l}0.14 * * \\
(2.09)\end{array}$ & $\begin{array}{c}0.75 * * * \\
(3.10)\end{array}$ & $\begin{array}{c}0.21 * * \\
(2.48)\end{array}$ & $\begin{array}{c}0.42 * * \\
(2.15)\end{array}$ & $\begin{array}{c}0.35 * * \\
(2.37)\end{array}$ & $\begin{array}{c}1.60 * * * \\
(3.06)\end{array}$ & $\begin{array}{c}0.14 \\
(0.49)\end{array}$ \\
\hline 1850 & $\begin{array}{c}1.02 * * * \\
(8.07)\end{array}$ & $\begin{array}{c}0.43 * * * \\
(8.17)\end{array}$ & $\begin{array}{c}1.99 * * * \\
(7.70)\end{array}$ & $\begin{array}{c}0.37 * * * \\
(5.45)\end{array}$ & $\begin{array}{c}1.24 * * * \\
(3.29)\end{array}$ & $\begin{array}{c}0.36^{* * *} \\
(4.02)\end{array}$ & $\begin{array}{c}1.22 * * * \\
(4.01)\end{array}$ & $\begin{array}{c}0.91 * * * \\
(5.20)\end{array}$ & $\begin{array}{l}1.87 * * \\
(2.38)\end{array}$ & $\begin{array}{c}-0.12 \\
(-0.42)\end{array}$ \\
\hline 1860 & $\begin{array}{c}2.11 * * * \\
(5.78)\end{array}$ & $\begin{array}{c}0.60 * * * \\
(11.46)\end{array}$ & $\begin{array}{c}3.31 * * * \\
(7.68)\end{array}$ & $\begin{array}{c}0.62 * * * \\
(8.94)\end{array}$ & $\begin{array}{c}3.07 * * * \\
(2.85)\end{array}$ & $\begin{array}{c}0.65 * * * \\
(7.02)\end{array}$ & $\begin{array}{c}3.31 * * * \\
(3.1)\end{array}$ & $\begin{array}{c}0.85 * * * \\
(4.96)\end{array}$ & $\begin{array}{c}2.79 * * * \\
(3.07)\end{array}$ & $\begin{array}{c}0.07 \\
(0.26)\end{array}$ \\
\hline 1870 & $\begin{array}{c}-0.16 \\
(-0.11)\end{array}$ & $\begin{array}{c}0.71 * * * \\
(11.54)\end{array}$ & $\begin{array}{c}1.96 \\
(1.36)\end{array}$ & $\begin{array}{c}0.76^{* * *} \\
(9.61)\end{array}$ & $\begin{array}{c}1.18 \\
(0.80)\end{array}$ & $\begin{array}{c}0.80 * * * \\
(7.47)\end{array}$ & & $\begin{array}{c}0.91 * * * \\
(4.66)\end{array}$ & & $\begin{array}{l}0.47 * \\
(1.66)\end{array}$ \\
\hline 1880 & & $\begin{array}{c}0.76^{* * *} \\
(7.24)\end{array}$ & & $\begin{array}{c}0.86^{* * *} \\
(7.26)\end{array}$ & & $\begin{array}{c}0.80 * * * \\
(4.73)\end{array}$ & & $\begin{array}{c}0.93 * * * \\
(3.35)\end{array}$ & & $\begin{array}{c}0.77 * * \\
(2.53) \\
\end{array}$ \\
\hline Time of imprisonm & & & & & & & & & & \\
\hline During the Famine & $\begin{array}{c}1.03 * * * \\
(10.89) \\
\text { reference }\end{array}$ & $\begin{array}{c}0.11^{* *} \\
(1.98) \\
\text { reference }\end{array}$ & reference & reference & $\begin{array}{c}0.75 \\
(0.98) \\
\text { reference }\end{array}$ & $\begin{array}{c}-0.19 \\
(-0.19) \\
\text { reference }\end{array}$ & $\begin{array}{c}0.57 \\
-0.59) \\
\text { reference }\end{array}$ & $\begin{array}{c}0.49 * \\
(1.88) \\
\text { reference }\end{array}$ & & \\
\hline
\end{tabular}




\begin{tabular}{|c|c|c|c|c|c|c|c|c|c|c|}
\hline \multicolumn{11}{|l|}{ Offences } \\
\hline \multirow[t]{2}{*}{ Against the person } & 0.03 & 0.00 & -0.38 & 0.03 & & 0.05 & -0.27 & -0.31 & $-1.00 *$ & 0.11 \\
\hline & $(0.35)$ & $(-0.09)$ & $(-1.49)$ & $(0.59)$ & & $(0.27)$ & $(-0.29)$ & $(-1.49)$ & $(-1.76)$ & $(1.00)$ \\
\hline \multirow[t]{2}{*}{ Property with violence } & $0.27 *$ & 0.12 & -0.12 & $0.25^{*}$ & & 1.11 & & 0.42 & & 0.14 \\
\hline & $(1.89)$ & $(1.48)$ & $(-0.23)$ & $(1.76)$ & & $(1.05)$ & & $(0.35)$ & & $(0.48)$ \\
\hline Property w/o violence & reference & reference & reference & reference & reference & reference & reference & reference & reference & reference \\
\hline \multirow[t]{2}{*}{ Begging and prostitution } & -0.09 & $-0.12 *$ & 0.13 & -0.13 & 1.8 & 0.13 & 0.83 & & 0.65 & 0.01 \\
\hline & $(-1.01)$ & $(-1.87)$ & $(0.31)$ & $(-1.09)$ & $(1.56)$ & $(0.22)$ & $(0.56)$ & & $(0.48)$ & $(0.04)$ \\
\hline \multirow[t]{2}{*}{ Drunkenness } & -0.02 & $0.11 * * *$ & -0.3 & 0.04 & & & 0.8 & -0.09 & 0.1 & 0.13 \\
\hline & $(-0.15)$ & $(2.64)$ & $(-1.47)$ & $(0.70)$ & & & $(0.77)$ & $(-0.51)$ & $(0.19)$ & $(1.31)$ \\
\hline \multirow[t]{2}{*}{$\begin{array}{l}\text { Indecency and public } \\
\text { disorder }\end{array}$} & $0.16 * *$ & -0.04 & $0.40 *$ & 0.03 & $0.70 * *$ & 0.04 & 0.27 & 0.22 & 0.31 & 0.1 \\
\hline & $(2.15)$ & $(-0.71)$ & $(1.77)$ & $(0.47)$ & $(2.05)$ & $(0.46)$ & $(1.22)$ & $(1.21)$ & $(0.40)$ & $(0.86)$ \\
\hline \multirow[t]{2}{*}{ Treason } & 0.43 & $0.28 * *$ & 10.08 & 0.09 & 0.36 & 11.64 & & & -0.1 & -0.22 \\
\hline & $(0.61)$ & $(2.36)$ & $(0.03)$ & $(0.54)$ & $(0.35)$ & $(0.02)$ & & & $(-0.18)$ & $(-0.63)$ \\
\hline \multirow[t]{2}{*}{ Rioting } & -0.69 & $-0.31 * *$ & -10.13 & -0.05 & & -11.82 & -1.06 & $-0.32 * *$ & & 0.12 \\
\hline & $(-0.98)$ & $(-2.43)$ & $(-0.03)$ & $(-0.30)$ & & $(-0.02)$ & $(-0.92)$ & $(-2.35)$ & & $(0.34)$ \\
\hline \multirow[t]{2}{*}{ Offence is unknown } & $0.18 * *$ & -0.05 & -0.21 & 0.06 & & & & & -0.34 & -0.15 \\
\hline & $(2.42)$ & $(-1.04)$ & $(-0.45)$ & $(0.63)$ & & & & & $(-0.34)$ & $(-0.87)$ \\
\hline \multicolumn{11}{|l|}{ Young age } \\
\hline \multirow[t]{2}{*}{ Aged 23-32 } & $0.12 *$ & $0.14 * * *$ & $-0.84 * * *$ & -0.02 & -0.12 & $-0.14^{* *}$ & 0.09 & 0.17 & -0.22 & $-0.22 *$ \\
\hline & $(1.67)$ & $(4.28)$ & $(-4.06)$ & $(-0.50)$ & $(-0.41)$ & $(-2.15)$ & $(0.47)$ & $(1.54)$ & $(-0.37)$ & $(-1.79)$ \\
\hline Aged 33 and over & reference & reference & reference & reference & reference & reference & reference & reference & reference & reference \\
\hline \multicolumn{11}{|l|}{ Recidivism } \\
\hline \multirow[t]{2}{*}{ Recidivist } & -0.06 & $0.23 * * *$ & $0.63 * * *$ & $0.41 * * *$ & $0.67 * * *$ & $0.46^{* * *}$ & -0.18 & $0.23 * *$ & $1.48 * * *$ & $0.50 * * *$ \\
\hline & $(-1.13)$ & $(8.07)$ & $(4.80)$ & $(11.24)$ & $(3.28)$ & $(8.96)$ & $(-1.08)$ & $(2.27)$ & $(3.72)$ & (6.19) \\
\hline One-time offender & reference & reference & reference & reference & reference & reference & reference & reference & reference & reference \\
\hline
\end{tabular}




\begin{tabular}{|c|c|c|c|c|c|c|c|c|c|c|}
\hline \multicolumn{11}{|l|}{ Denomination } \\
\hline $\begin{array}{l}\text { Protestant } \\
\text { Catholic }\end{array}$ & $\begin{array}{c}0.21 \\
(1.35) \\
\text { reference }\end{array}$ & $\begin{array}{l}0.36^{* * *} \\
(4.00) \\
\text { reference }\end{array}$ & $\begin{array}{c}-0.24 \\
(-0.53) \\
\text { reference }\end{array}$ & $\begin{array}{c}0.14 \\
(1.13) \\
\text { reference }\end{array}$ & $\begin{array}{c}0.45 \\
(0.71) \\
\text { reference }\end{array}$ & $\begin{array}{l}0.47 * \\
(1.92) \\
\text { reference }\end{array}$ & $\begin{array}{c}-0.49 \\
(-1.01) \\
\text { reference }\end{array}$ & $\begin{array}{l}0.3 \\
(0.96) \\
\text { reference }\end{array}$ & & $\begin{array}{c}0.59 \\
(1.64) \\
\text { reference }\end{array}$ \\
\hline \multicolumn{11}{|l|}{ Literacy } \\
\hline $\begin{array}{l}\text { Literate } \\
\text { Illiterate }\end{array}$ & $\begin{array}{l}0.18 * * * \\
(3.10) \\
\text { reference }\end{array}$ & $\begin{array}{l}0.25^{* * *} \\
(8.78) \\
\text { reference }\end{array}$ & $\begin{array}{c}-0.05 \\
(-0.33) \\
\text { reference }\end{array}$ & $\begin{array}{l}0.11 * * * \\
(3.00) \\
\text { reference }\end{array}$ & $\begin{array}{c}-0.21 \\
(-0.96) \\
\text { reference }\end{array}$ & $\begin{array}{l}0.11 * * \\
(2.21) \\
\text { reference }\end{array}$ & $\begin{array}{c}-0.32 * \\
(-1.87) \\
\text { reference }\end{array}$ & $\begin{array}{l}0.26^{* * *} \\
(2.77) \\
\text { reference }\end{array}$ & $\begin{array}{c}-0.14 \\
(-0.36) \\
\text { reference }\end{array}$ & $\begin{array}{c}0.11 \\
(1.27) \\
\text { reference }\end{array}$ \\
\hline \multicolumn{11}{|l|}{ Place of origin } \\
\hline $\begin{array}{l}\text { County Tipperary } \\
\text { Migrated to Co. Tipperary }\end{array}$ & $\begin{array}{l}0.50 * * * \\
(5.18) \\
\text { reference }\end{array}$ & $\begin{array}{l}0.12 * * * \\
(3.53) \\
\text { reference }\end{array}$ & & & $\begin{array}{c}0.21 \\
(0.93) \\
\text { reference }\end{array}$ & $\begin{array}{c}0.06 \\
(1.09) \\
\text { reference }\end{array}$ & $\begin{array}{l}0.93 * * * \\
(4.46) \\
\text { reference }\end{array}$ & $\begin{array}{c}0.37 * * * \\
(3.34) \\
\text { reference }\end{array}$ & $\begin{array}{c}0.34 \\
(0.83) \\
\text { reference }\end{array}$ & $\begin{array}{c}0.01 \\
(0.12) \\
\text { reference }\end{array}$ \\
\hline \multicolumn{11}{|l|}{ Occupational class } \\
\hline $\begin{array}{l}\text { Low (Armstrong } 1 \text { \& 2) } \\
\text { Medium (Armstrong 3) }\end{array}$ & & & $\begin{array}{c}0.23 \\
(1.36) \\
\text { reference }\end{array}$ & $\begin{array}{c}0.02 \\
(0.46) \\
\text { reference }\end{array}$ & & & & & & \\
\hline High (Armstrong 4 \& 5) & & & & $\begin{array}{c}0.19 \\
(1.05)\end{array}$ & & & & & & \\
\hline Farmers (Armstrong 6) & & & $\begin{array}{c}-0.14 \\
(-0.24)\end{array}$ & $\begin{array}{c}-0.23 * * * \\
(-2.76)\end{array}$ & & & & & & \\
\hline \multicolumn{11}{|l|}{ Marital status } \\
\hline Single & & & & & & & & & $\begin{array}{c}0.91 \\
(0.54)\end{array}$ & $\begin{array}{c}-0.02 \\
(-0.28)\end{array}$ \\
\hline Married & & & & & & & & & reference & reference \\
\hline Widowed & & & & & & & & & & $\begin{array}{c}0.14 \\
(0.85)\end{array}$ \\
\hline
\end{tabular}




\begin{tabular}{lcccccccccc} 
Constant & $-0.62 * * *$ & 0.06 & $-1.01^{* * *}$ & $0.23 * * *$ & $-1.06^{* * *}$ & $0.22^{* * *}$ & 0.19 & -0.02 & $-1.71^{* *}$ & 0.48 \\
& $(-7.27)$ & $(1.16)$ & $(-3.78)$ & $(2.83)$ & $(-3.56)$ & $(2.77)$ & $(0.16)$ & $(-0.10)$ & $(-2.48)$ & $(1.64)$ \\
\hline Observations & 7,652 & 27,564 & 1,295 & 16,869 & 513 & 8,804 & 792 & 2,493 & 186 & 4,198 \\
\hline
\end{tabular}

Notes: Numeracy measured by a non-rounded age statement (odds ratios). * = Statistically significant at the $10 \%$ level; $* *=$ Statistically significant at the $5 \%$ level; $* * *=$

Statistically significant at the $1 \%$ level. We used Armstrong's occupation classification system to distinguish individuals by the level of sophistication of their occupation; unskilled and semi-skilled occupations (Armstrong classes 1 and 2) are used to identify a 'low' category, skilled occupations (Armstrong class 3) is our middle class, and semi-professional and professional occupations (classes 4 and 5) refer to our 'high' class. 
Table 3. Descriptive statistics (percentages), Thurles workhouse inmates, by gender

\begin{tabular}{|c|c|c|c|}
\hline & & $\begin{array}{c}\text { Females } \\
(\text { in } \%)\end{array}$ & $\begin{array}{l}\text { Males } \\
(\text { in } \%)\end{array}$ \\
\hline \multirow[t]{2}{*}{ Numeracy } & Numerate & 45 & 51 \\
\hline & Non-numerate & 55 & 49 \\
\hline \multirow[t]{9}{*}{ Birth decade } & 1800 & 2 & 1 \\
\hline & 1810 & 6 & 4 \\
\hline & 1820 & 6 & 6 \\
\hline & 1830 & 11 & 13 \\
\hline & 1840 & 18 & 20 \\
\hline & 1850 & 17 & 19 \\
\hline & 1860 & 21 & 19 \\
\hline & 1870 & 14 & 13 \\
\hline & 1880 & 5 & 4 \\
\hline \multirow[t]{3}{*}{ Admission year } & 1880 & 7 & 5 \\
\hline & 1889 & 30 & 33 \\
\hline & All other years & 63 & 62 \\
\hline \multirow[t]{2}{*}{ Young age } & Aged 23-32 & 39 & 28 \\
\hline & Aged 33 and over & 61 & 72 \\
\hline \multirow[t]{2}{*}{ Denomination } & Protestant & 1 & 2 \\
\hline & Catholic & 99 & 98 \\
\hline \multirow[t]{3}{*}{ Marital status } & Single & 25 & 74 \\
\hline & Married & 55 & 20 \\
\hline & Widowed & 20 & 6 \\
\hline \multirow[t]{2}{*}{ Death in workhouse? } & Yes & 4 & 2 \\
\hline & No & 96 & 84 \\
\hline \multirow[t]{3}{*}{ Quality of clothing } & $\mathrm{Bad}$ & 19 & 13 \\
\hline & Middle or good & 6 & 3 \\
\hline & Unknown & 75 & 84 \\
\hline Number of inmates & & 1,478 & 3,290 \\
\hline
\end{tabular}

Sources: Authors' calculations using Crossman, 'Welfare regimes under the Irish Poor Law 1850-1921', UK Data Archive. 
Table 4. Determinants of numeracy (odds ratios), Thurles workhouse inmates

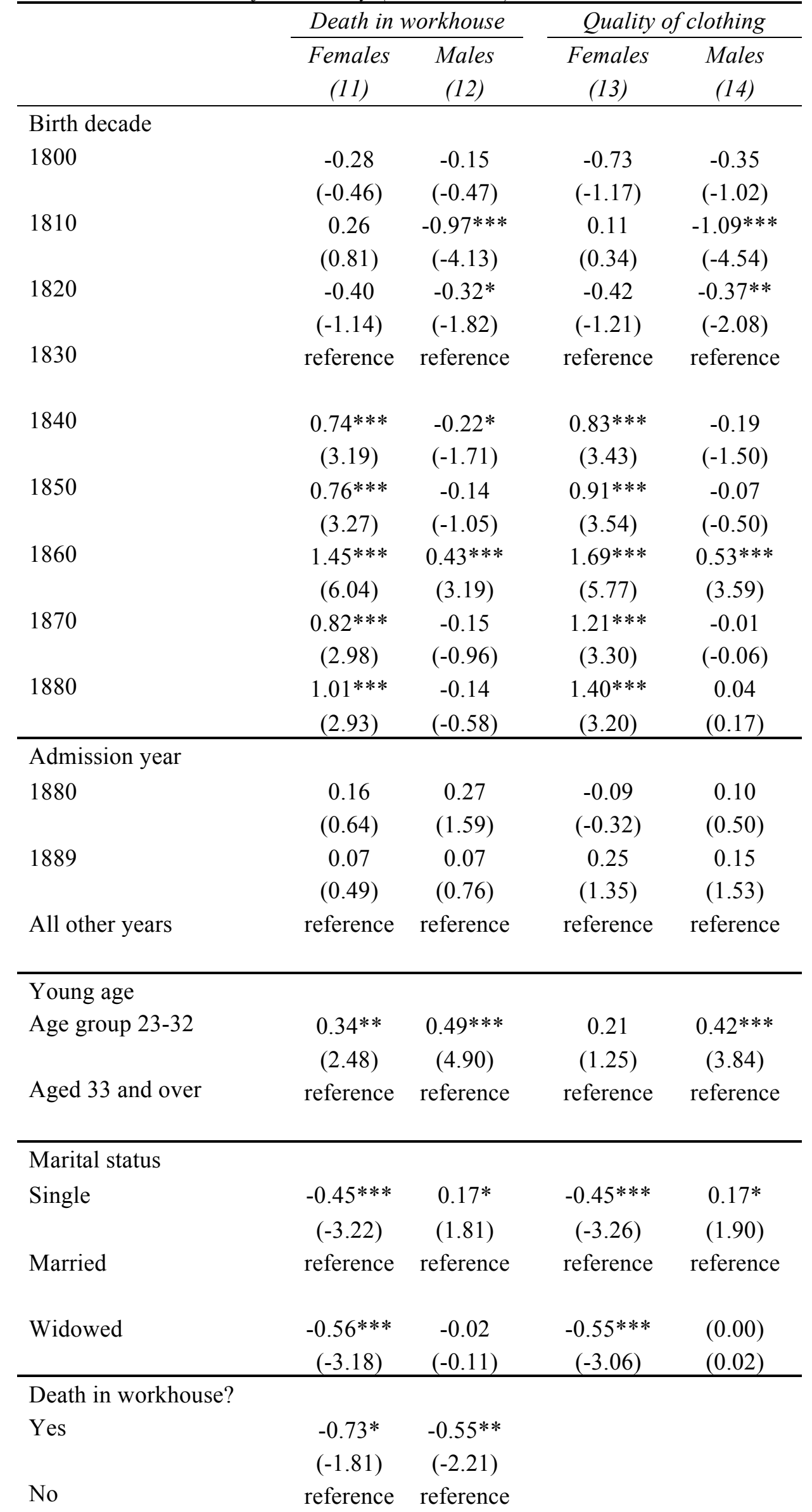




\begin{tabular}{|c|c|c|c|c|}
\hline \multicolumn{5}{|c|}{ Quality of clothing } \\
\hline \multirow[t]{2}{*}{$\mathrm{Bad}$} & & & 0.20 & 0.11 \\
\hline & & & $(0.69)$ & $(0.44)$ \\
\hline \multicolumn{3}{|l|}{ Middle or good } & reference & reference \\
\hline \multirow[t]{2}{*}{ Unknown } & & & -0.25 & -0.16 \\
\hline & & & $(-0.76)$ & $(-0.68)$ \\
\hline \multirow[t]{2}{*}{ Constant } & $-1.35 * * *$ & -0.00 & $-1.34 * * *$ & 0.06 \\
\hline & $(-6.17)$ & $(-0.01)$ & $(-4.27)$ & $(0.25)$ \\
\hline Observations & 1,478 & 3,290 & 1,478 & 3,290 \\
\hline
\end{tabular}

Notes: Numeracy measured by a non-rounded age statement (odds ratios). $*$ = Statistically significant at the $10 \%$ level; ** $=$ Statistically significant at the $5 \%$ level; $* * *=$ Statistically significant at the $1 \%$ level. 
Table 5: ABCC scores calculated using various census, prison and workhouse samples

(a) Females

\begin{tabular}{lccccc}
\hline $\begin{array}{l}\text { Birth } \\
\text { decade }\end{array}$ & $\begin{array}{c}\text { Tipperary } \\
\text { (1841 census) }\end{array}$ & $\begin{array}{c}\text { Tipperary } \\
\text { (1871 census) }\end{array}$ & $\begin{array}{c}\text { Clonmel } \\
\text { prisoners }\end{array}$ & $\begin{array}{c}\text { Clonmel prisoners } \\
\text { (conv. post-1870) }\end{array}$ & $\begin{array}{c}\text { Workhouse } \\
\text { inmates }\end{array}$ \\
\hline 1770 & 63.1 & & & & \\
1780 & 46.5 & & 43.8 & & \\
1790 & 58.6 & & 21.3 & & \\
1800 & 63.2 & 61.5 & 28.8 & 11.3 & \\
1810 & 71.5 & 52.6 & 23.8 & 17.5 & 42.5 \\
1820 & & 51.7 & 45.0 & 33.8 & 26.3 \\
1830 & & 60.2 & 60.0 & 31.3 & 35.0 \\
1840 & & 74.3 & 71.3 & 60.0 & 56.3 \\
1850 & & & 88.8 & 93.8 & 56.3 \\
1860 & & & & & 77.5 \\
1870 & & & & & 58.8 \\
1880 & & & & & 63.8 \\
\hline
\end{tabular}

(b) Males

\begin{tabular}{lccccc}
\hline $\begin{array}{l}\text { Birth } \\
\text { decade }\end{array}$ & $\begin{array}{c}\text { Tipperary } \\
\text { (1841 census) }\end{array}$ & $\begin{array}{c}\text { Tipperary } \\
\text { (1871 census) }\end{array}$ & $\begin{array}{c}\text { Clonmel } \\
\text { prisoners }\end{array}$ & $\begin{array}{c}\text { Clonmel prisoners } \\
\text { (conv. post-1870) }\end{array}$ & $\begin{array}{c}\text { Workhouse } \\
\text { inmates }\end{array}$ \\
\hline 1770 & 71.1 & & & & \\
1780 & 59.3 & & 72.5 & & \\
1790 & 65.7 & & 63.8 & & \\
1800 & 68.2 & 70.4 & 53.8 & 75.0 & \\
1810 & 77.6 & 55.2 & 56.3 & 80.0 & 37.5 \\
1820 & & 56.4 & 76.3 & 76.3 & 56.3 \\
1830 & & 65.5 & 76.3 & 73.8 & 66.3 \\
1840 & & 77.8 & 82.5 & 81.3 & 60.0 \\
1850 & & & 88.8 & 90.0 & 62.5 \\
1860 & & & 92.5 & 95.0 & 78.8 \\
1870 & & & 95.0 & 97.5 & 61.3 \\
1880 & & & 96.3 & 100.0 & 62.5 \\
\hline
\end{tabular}


Table 6: Delta computation using various census, prison and workhouse samples

\begin{tabular}{|c|c|c|c|c|c|c|c|c|c|c|}
\hline \multirow[t]{3}{*}{$\begin{array}{l}\text { Birth } \\
\text { decade }\end{array}$} & \multicolumn{2}{|c|}{$\begin{array}{c}\text { Prisoners } \\
\text { (full population) }\end{array}$} & \multicolumn{2}{|c|}{$\begin{array}{c}\text { Prisoners } \\
\text { (drunkards) }\end{array}$} & \multicolumn{2}{|c|}{$\begin{array}{l}\text { Prisoners } \\
\text { (political) }\end{array}$} & \multicolumn{2}{|c|}{$\begin{array}{c}\text { Prisoners } \\
\text { (imprisoned post-1870) }\end{array}$} & \multicolumn{2}{|c|}{$\begin{array}{c}\text { Workhouse inmates } \\
\text { (full population) }\end{array}$} \\
\hline & $(1841$ & $(1871$ & $(1841$ & $(1871$ & $(1841$ & $(1871$ & $(1841$ & $(1871$ & $(1841$ & $(1871$ \\
\hline & census) & census) & census) & census) & census) & census) & census) & census) & census) & census) \\
\hline 1780 & 15.9 & & & & & & & & & \\
\hline 1790 & 35.5 & & & & & & & & & \\
\hline 1800 & 19.9 & 16.1 & & & & & 58.7 & 54.9 & & \\
\hline 1810 & 26.4 & 29.9 & 62.7 & 66.2 & 50.2 & -2.6 & 56.4 & 59.9 & -11.1 & -7.6 \\
\hline 1820 & & 26.6 & & 29.1 & & 2.8 & & 37.8 & & 25.3 \\
\hline 1830 & & 11.0 & & 24.7 & & 2.2 & & 37.2 & & 26.0 \\
\hline 1840 & & 7.8 & & 10.3 & & 15.3 & & 17.8 & & 0.3 \\
\hline
\end{tabular}

Notes: Mean and median values for all deltas shown are 26.0 and 25.3. 
Figure 1. Age distribution of the general population, aged 23-72, by gender

(a) 1841 census

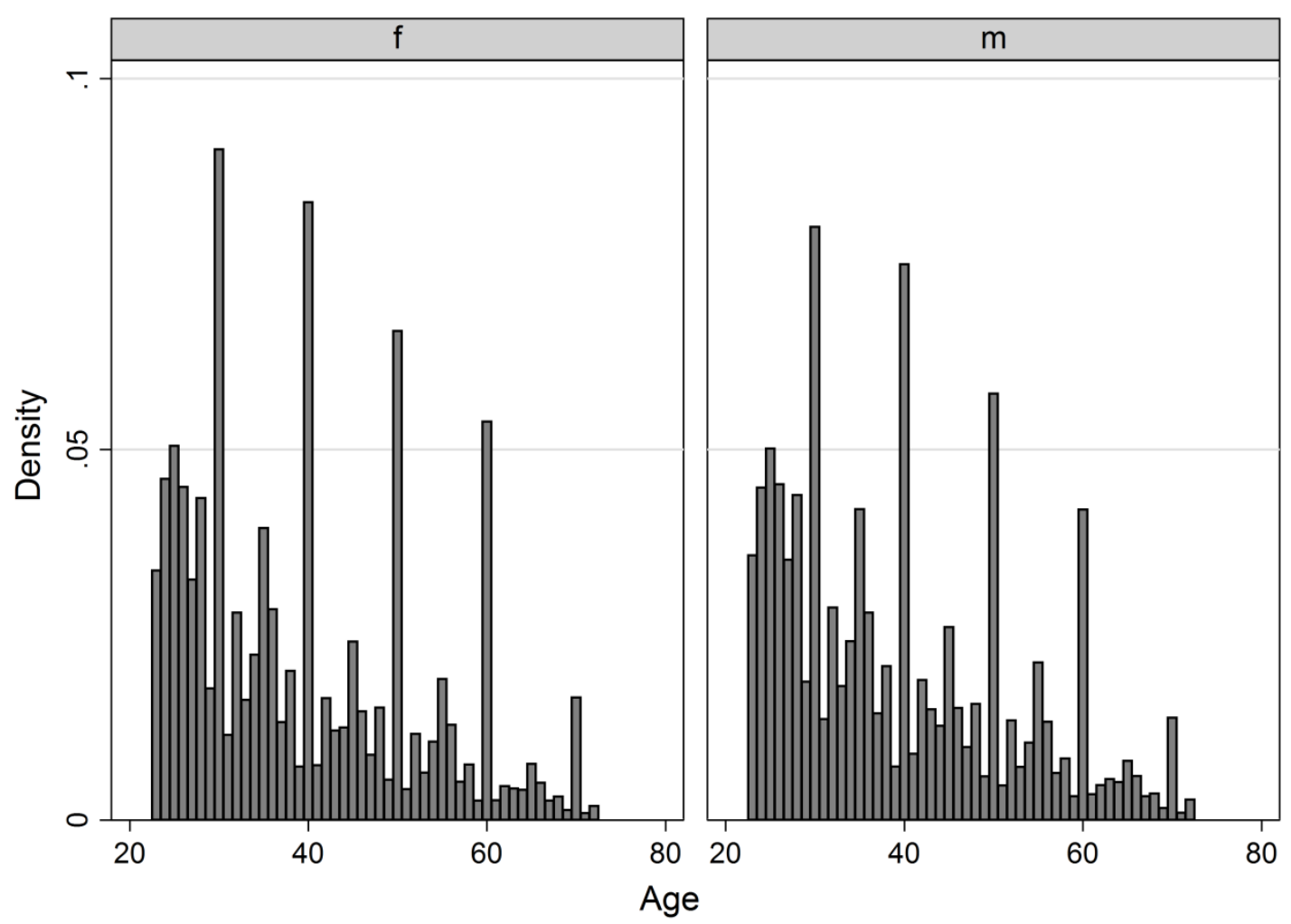

(b) 1871 census

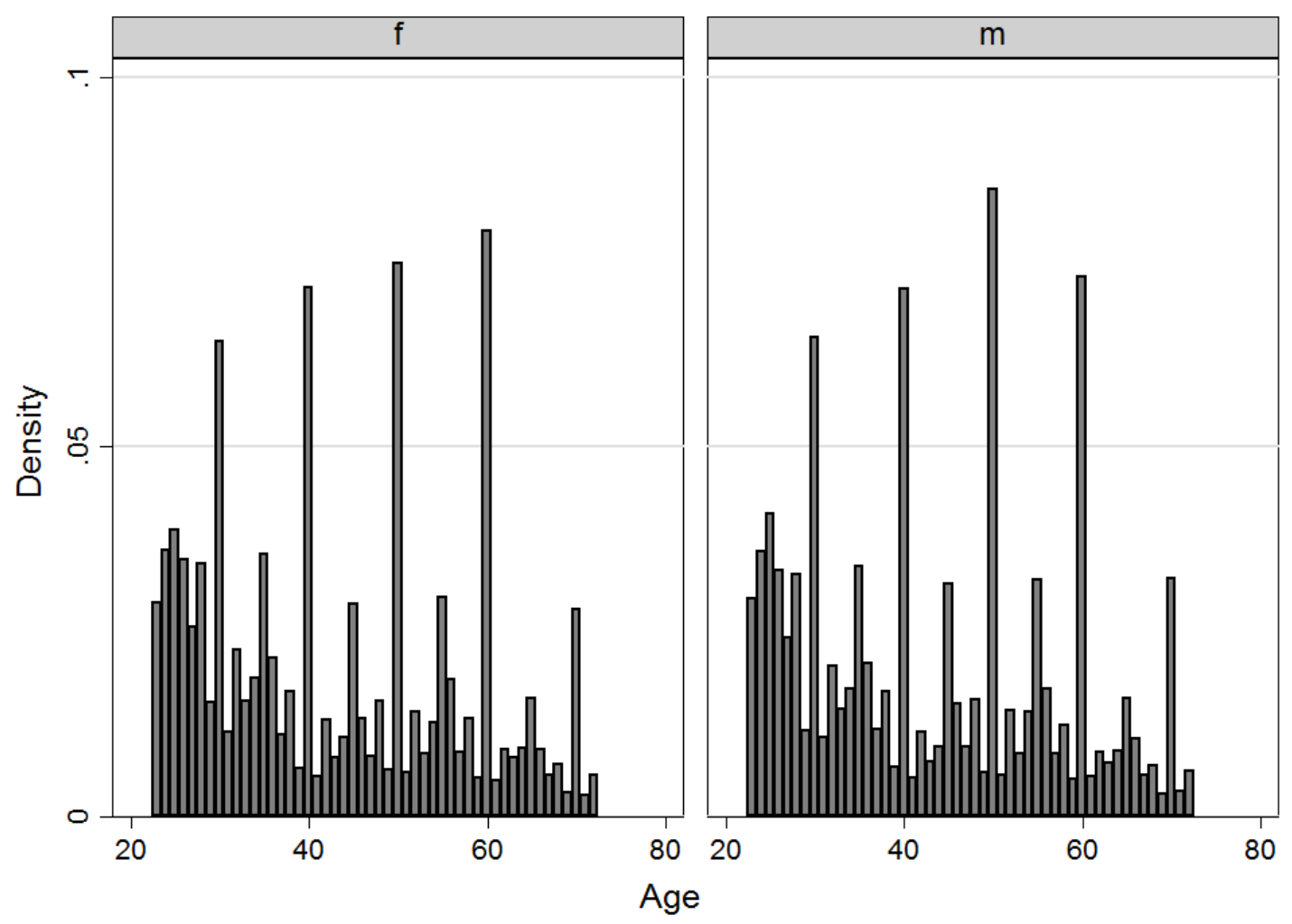

Notes: $\mathrm{f}=$ females $; \mathrm{m}=$ males. 
Figure 2. Age distribution of the institutionalised population, aged 23-72, by gender

(a) Clonmel Gaol prisoners

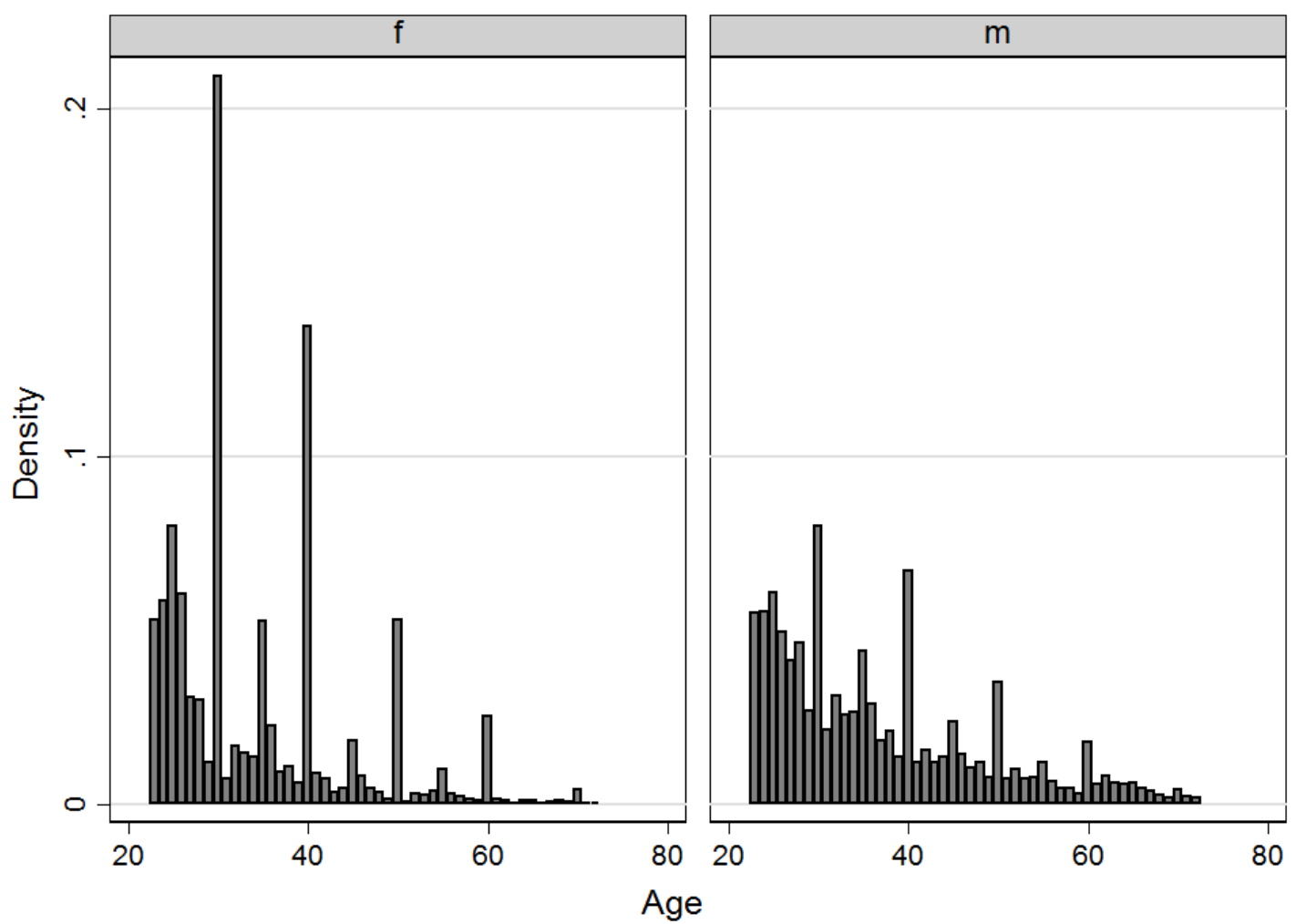

(b) Thurles workhouse inmates

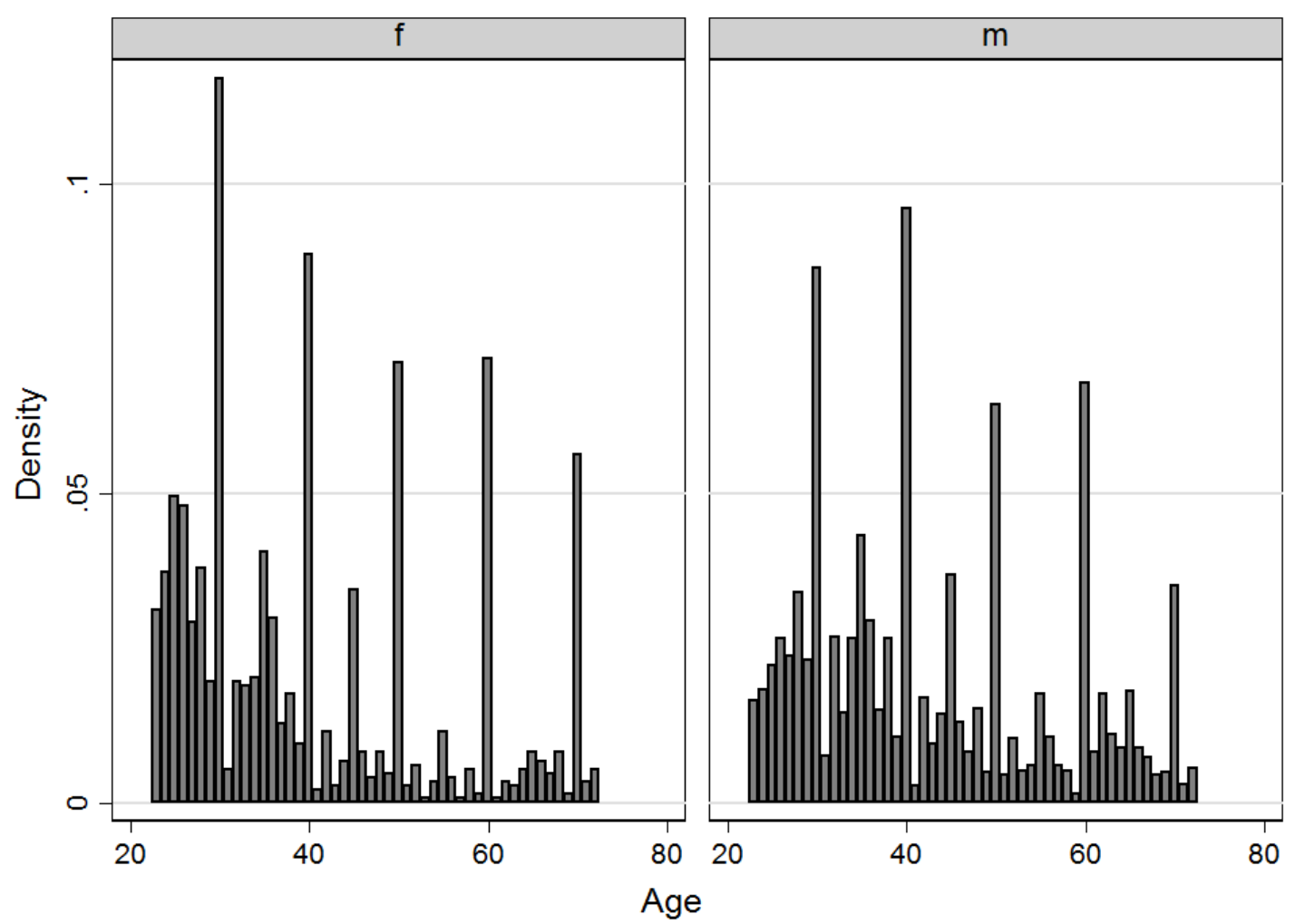


Figure 3. Approximate year of birth of the institutionalised population, aged 23-72, by gender

(a) Clonmel Gaol prisoners

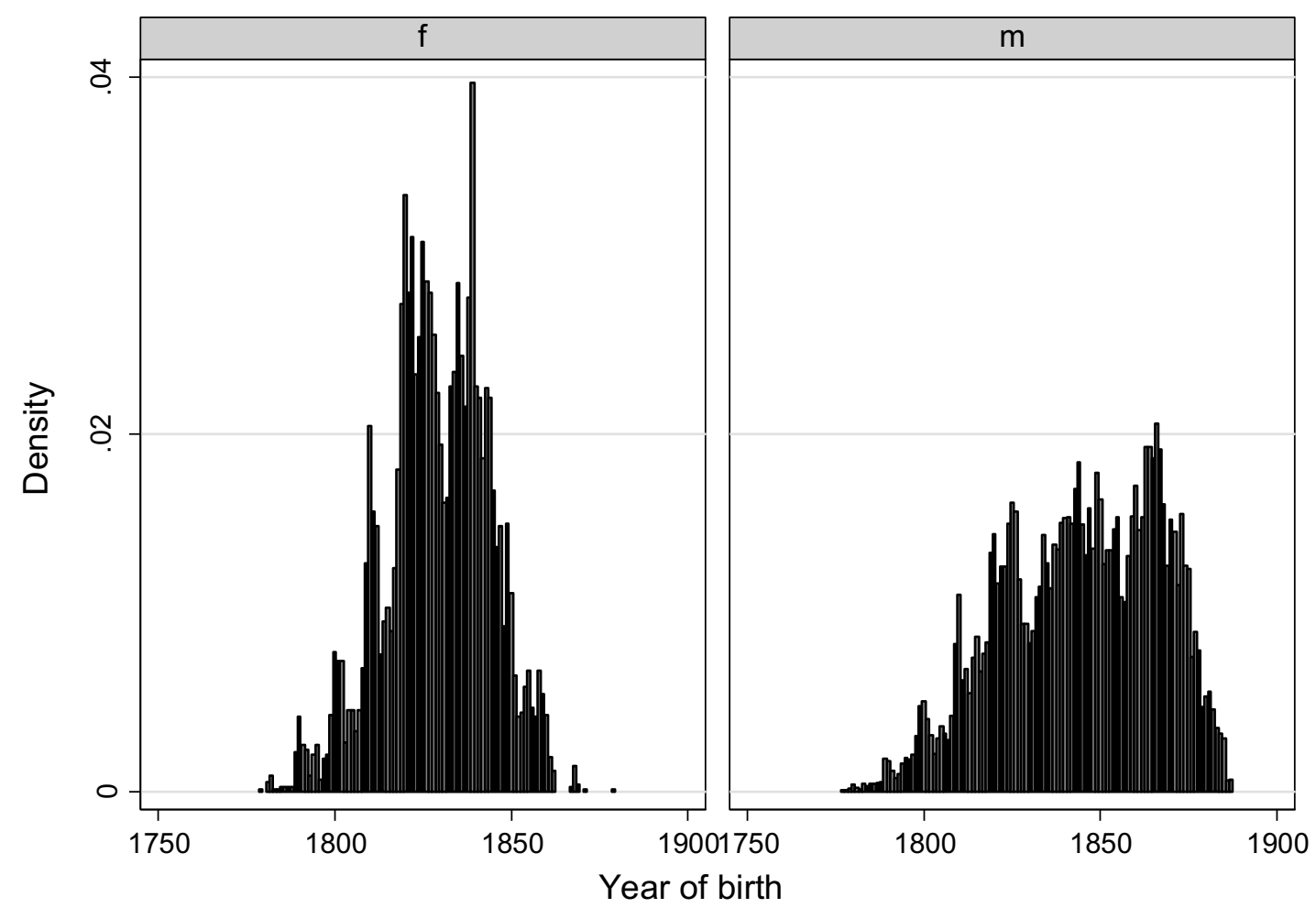

(b) Thurles workhouse inmates

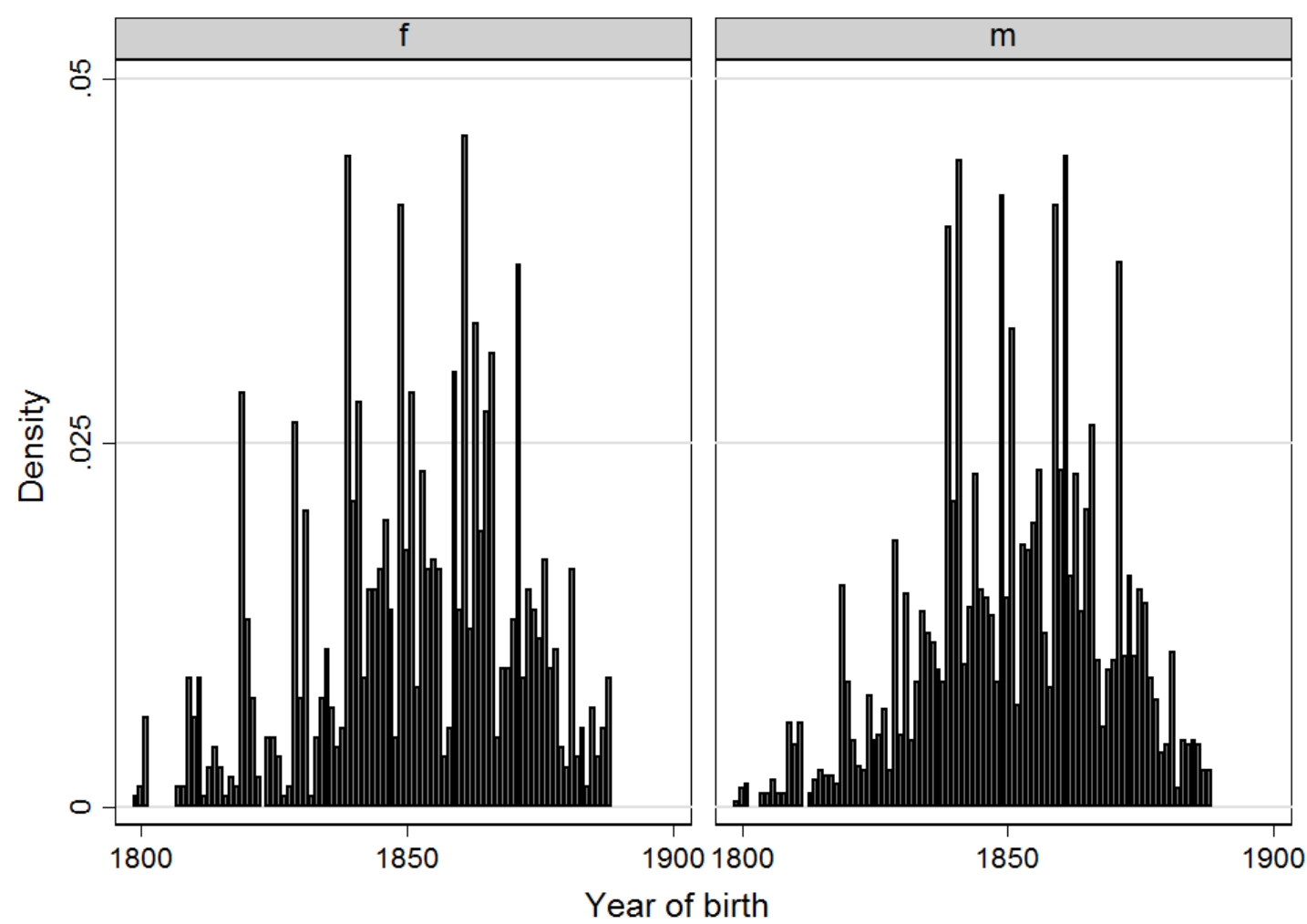


Figure 4. Year of entry into institution, aged 23-72, by gender

(a) Clonmel Gaol prisoners

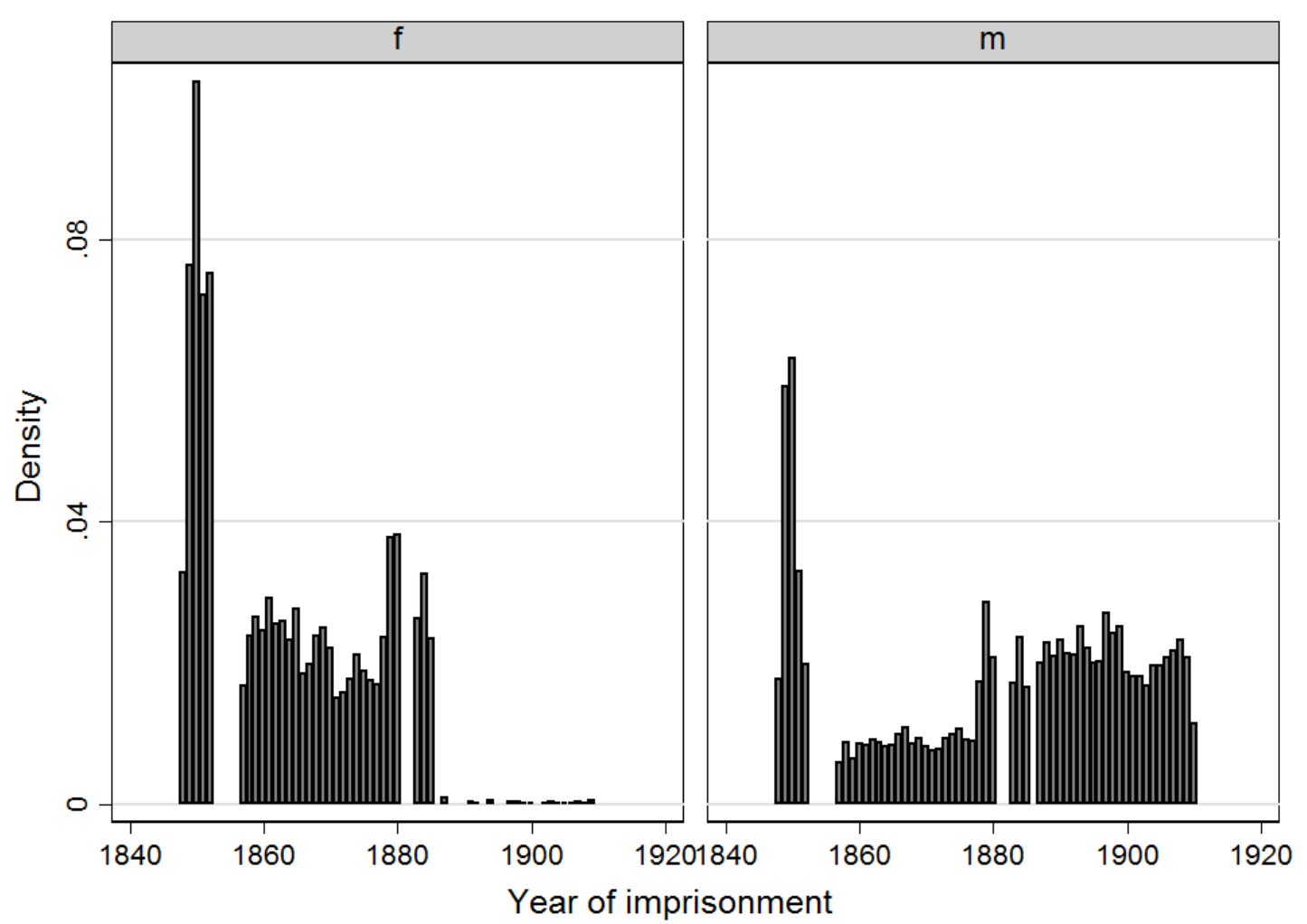

(b) Thurles workhouse inmates

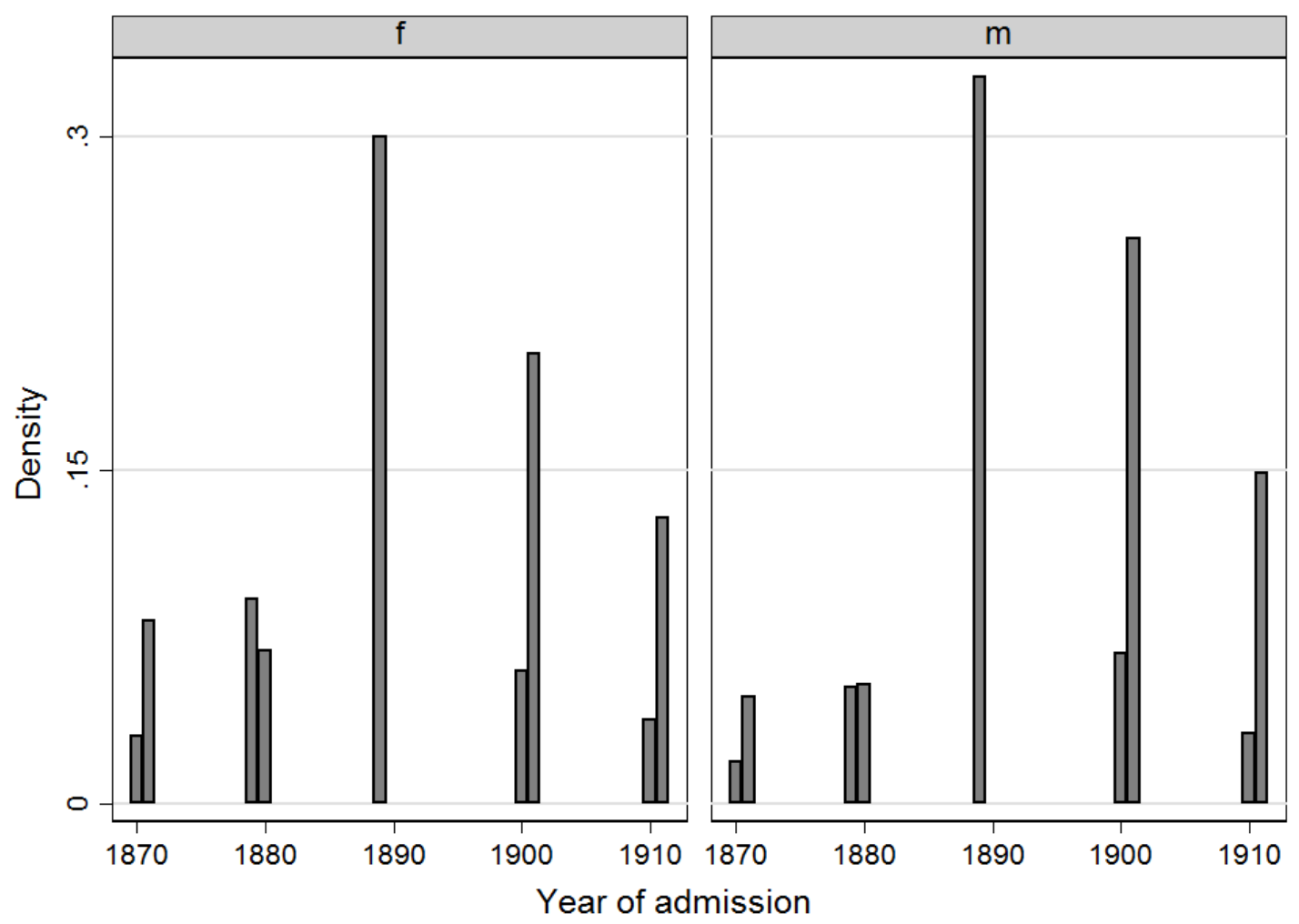


Figure 5. Offence by year of imprisonment, aged 23-72, females and males pooled
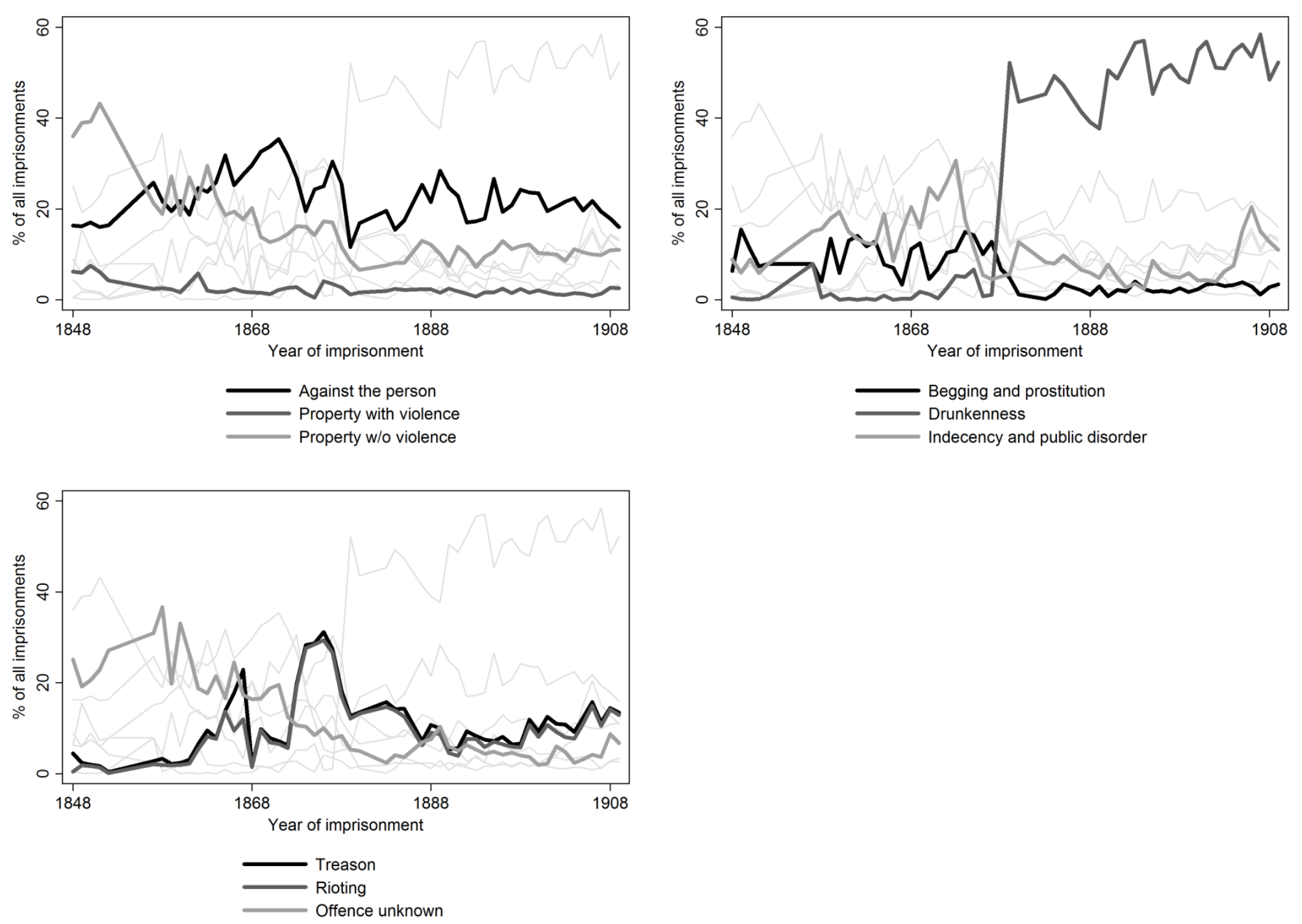
Figure 6. Numeracy trends (ABCC), 1770s-1880s, by gender
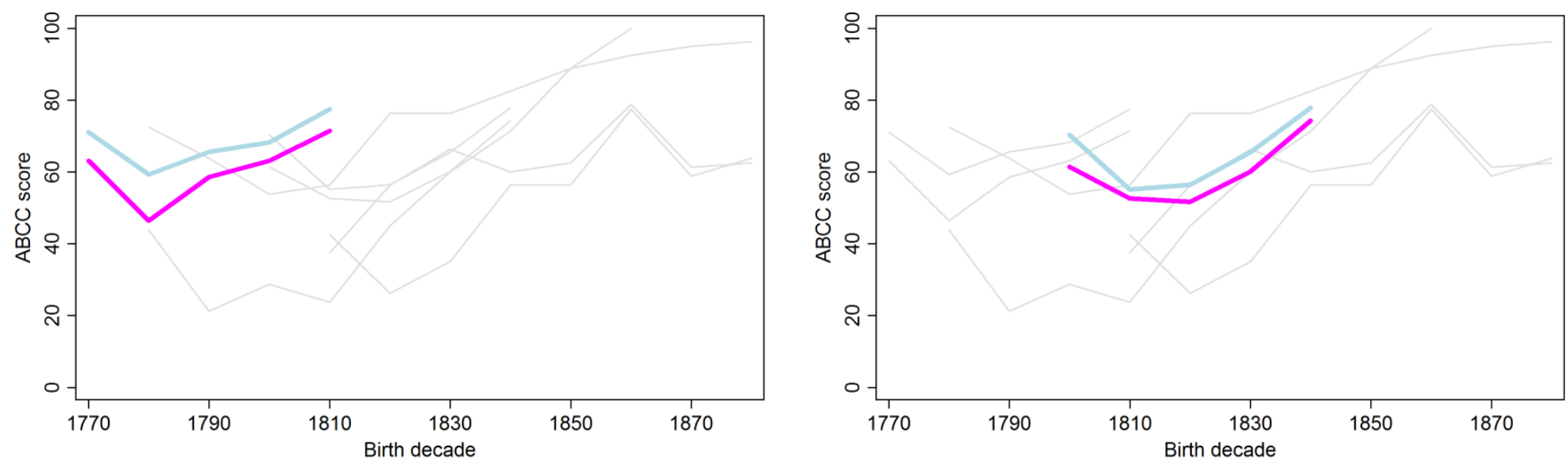

Tipperary population, 1841 census ( $m$ )

Tipperary population, 1841 census (f)
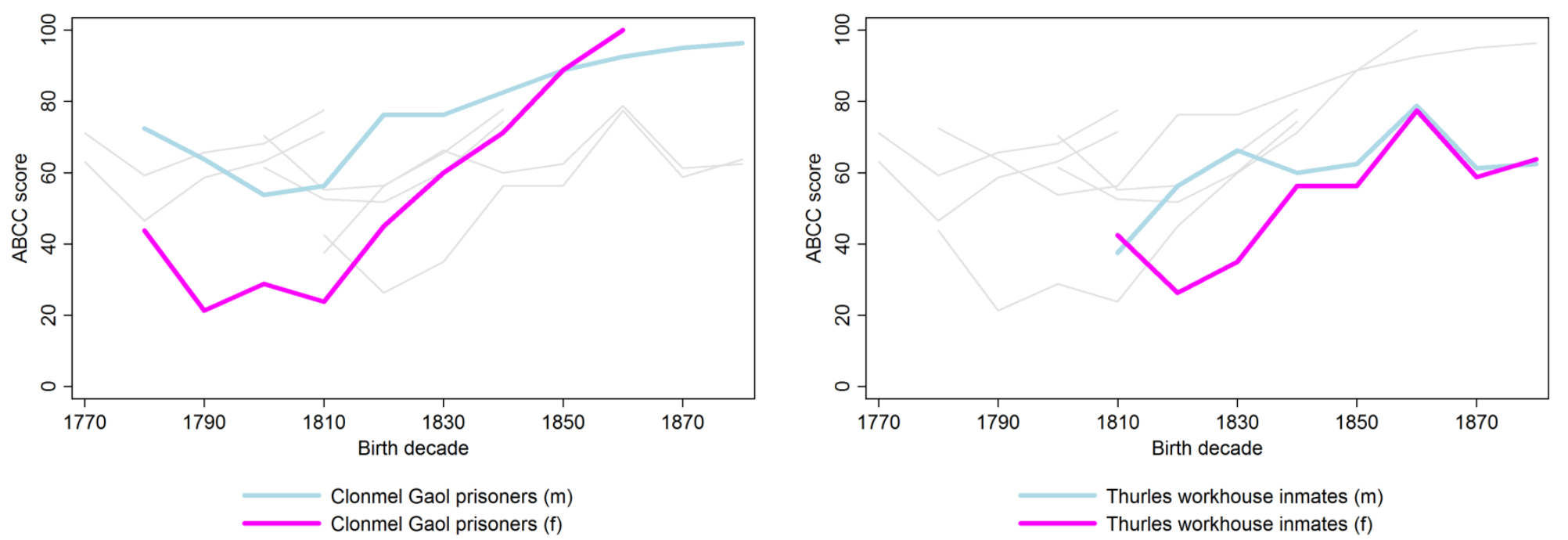

Notes: $\mathrm{m}=$ males (blue); $\mathrm{f}=$ females (pink). All cohorts and their ABCC values are ordered by birth decade. 
Figure 7. Numeracy trends (ABCC), 1780s-1880s, by gender and prisoner sub-group
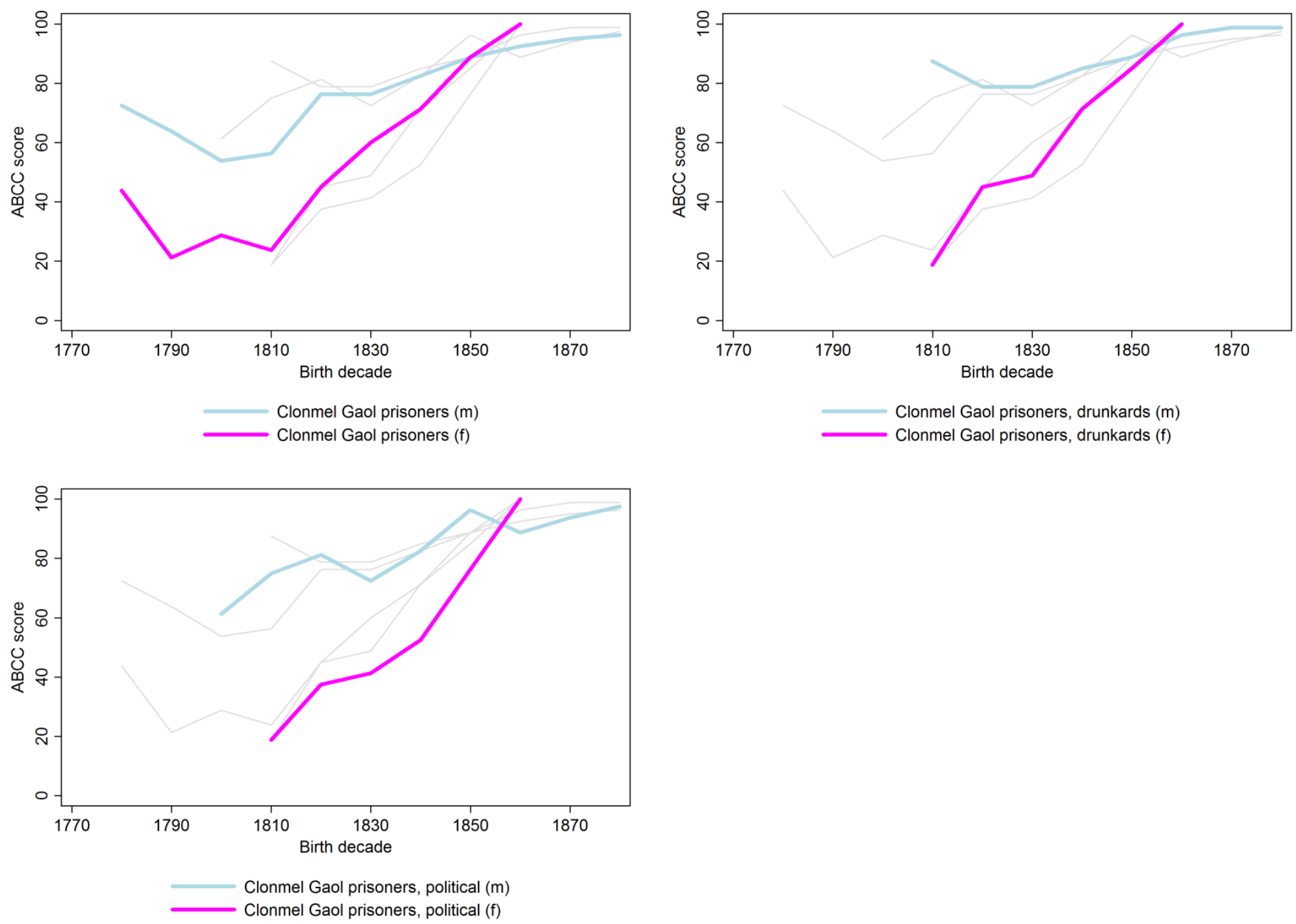

Notes: $\mathrm{m}=$ males (blue); $\mathrm{f}=$ females (pink). All cohorts and their $\mathrm{ABCC}$ values are ordered by birth decade. 
Figure 8. Numeracy trends (ABCC), 1770s-1880s, emigrants and non-emigrants

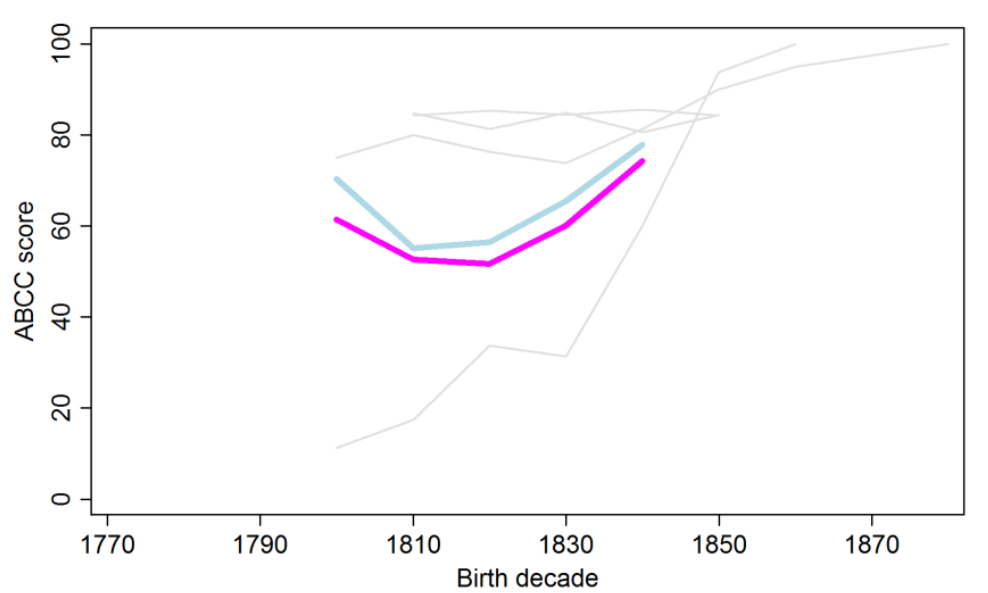

Tipperary population, 1871 census (m)

Tipperary population, 1871 census (f)

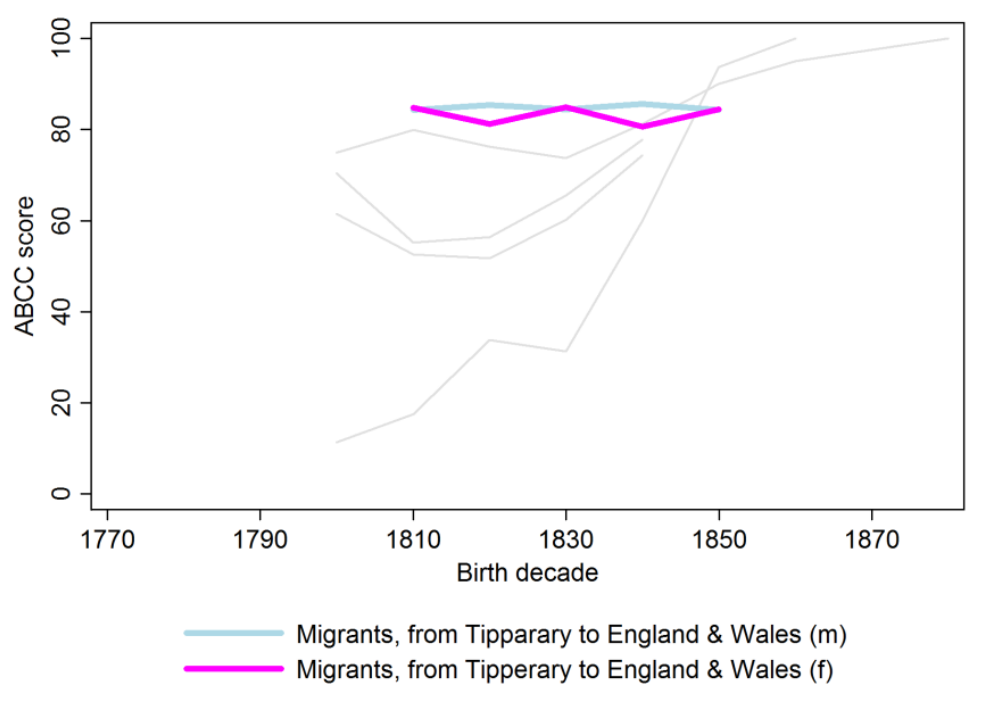

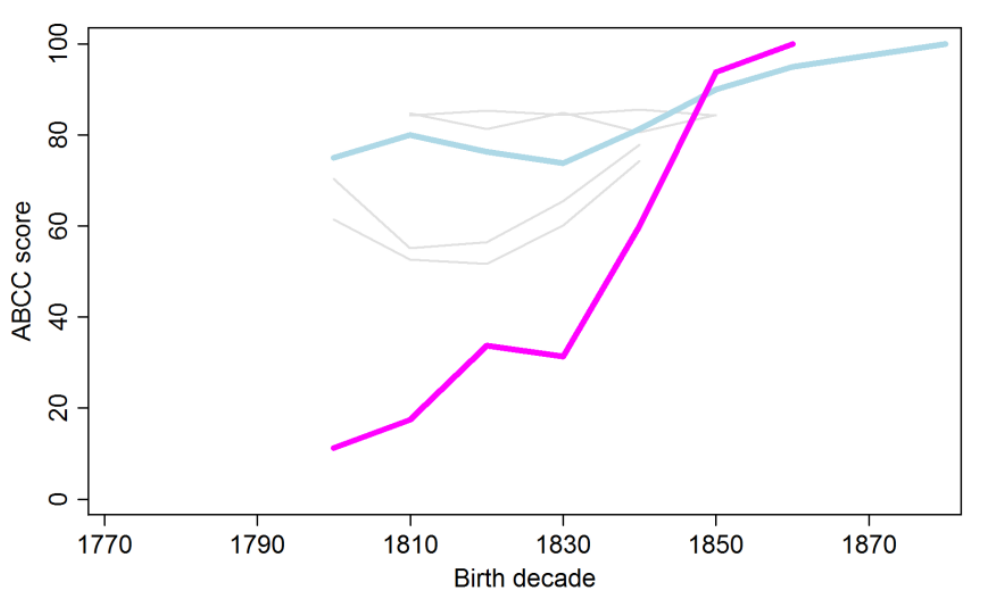

Clonmel Gaol prisoners, convicted post-1870 (m) Clonmel Gaol prisoners, convicted post-1870 (f)

Notes: $\mathrm{m}=$ males (blue); $\mathrm{f}=$ females (pink). All cohorts and their ABCC values are ordered by birth decade. 


\section{APPENDIX S1: ADDITIONAL RESULTS}

We provide additional analyses of two other prisons on the island of Ireland: Castlebar Gaol, located in County Mayo, and Kilmainham Gaol, in County Dublin. ${ }^{\text {F1 }}$ These offer an interesting basis for comparison with the results for Clonmel; while Castlebar is even more rural, Kilmainham is located in the capital and houses prisoners from across Ireland. ${ }^{\mathrm{F} 2} \mathrm{We}$ find that our $\Delta_{t}$ values - the differences in the differences - for both Castlebar and Kilmainham are positive and also larger for earlier cohorts, but decrease in size and in a single case is negative (Castlebar for the 1840s birth cohort). These results, reported in tables $\mathrm{S} 1$ and S2, are consistent with our earlier conclusions in the main text of this article: there was considerable convergence of female human capital, convergence that cannot be detected using census data alone. Given the location of these other prisons, we are confident that our interpretation for Tipperary is therefore generally applicable to the whole of the island.

The regions and prisons used in these robustness exercises are contextualised as follows. Mayo was predominantly agricultural prior to the 1820s; Castlebar had protoindustrial sectors with a particular emphasis on textile weaving. Politically, Mayo was the epicentre of the Irish National Land League, a nationalist organisation championing tenant farmers which was founded in Castlebar by Michael Davitt in 1879. The county had a large proportion of small farmers who grew oats for export, barley for (illicit) distilling, flax for local linen manufacture and potatoes for consumption. Smallholders, whose farms were getting smaller as their families got bigger, became single crop farmers, with little land available for cash crops. ${ }^{\text {F3 }}$ Only middle-sized farmers and the gentry were able to participate in the export market to any appreciable degree. As a whole, there was an overreliance on potatoes in Mayo and so the county suffered particularly badly in the Great Famine. ${ }^{\text {F4 }}$

The county surrounding Dublin was predominantly agricultural in nature, although the areas immediately surrounding the city of Dublin increasingly expanded into suburbs over the nineteenth century. Unlike Castlebar and Clonmel, Dublin had greater industrial and service activity. Dublin was home to a major brewery (Guinness) and distillery (Jameson) and also had a large financial services centre: it was home of the Bank of Ireland. Major cattle fairs were held on the outskirts of the city (Smithfield) with farmers coming from the

\footnotetext{
${ }^{\text {F1 }}$ All the extant prison registers of Castlebar Gaol (1878-1919) and Kilmainham Gaol (1798-1910) are held at the National Archive of Ireland, Dublin (Pris1/MRGS 51/2 and Pris1/MRGS 51/20).

F2 These are also the prisons used by Ó Gráda, Ireland, in his anthropometric study of Irish living standards.

F3 Jordan, Land, p. 57.

${ }^{\mathrm{F} 4}$ Mokyr, Why Ireland starved, p. 267.
} 
neighbouring countryside. During the Famine migrants from the countryside came to Dublin en route to the port of Liverpool, but many migrants remained in the city.

Castlebar has a history of prison buildings being located in the centre of the town that date back to late medieval and early modern precursors. Castlebar had at least two prisons in the 1700 s, including a Bridewell that opened in 1786. The prison records that are accessible via the National Archives of Ireland do not cover the full period of this study. The County Gaol for Mayo, situated in Castlebar, dates from 1834 to 1919, but the prison records only date from 1878. The dearth in earlier records for Castlebar is due to it being a county gaol that was not part of the Irish Convict System on establishment. This system was initiated between 1853 and 1857 and established a centralised government-controlled convict prisons, but was not effective nationally until the legislative changes of $1877 .{ }^{\mathrm{F} 5}$ Previous to this legislation, Castlebar had been administered at local level and its record keeping was not maintained to the requisite standards of the newly introduced system.

Kilmainham was founded as the Dublin County Gaol and was located in an established institutional landscape, built beside the military barracks of Royal Kilmainham, on the outskirts of Dublin City. The 'new' Kilmainham Gaol was built in 1796, replacing the 'old' Kilmainham Gaol located nearby. The new gaol operated as a functioning prison from 1796 to 1910 and housed British soldiers on an ad hoc basis immediately after closure. It was reopened in the aftermath of the Easter Rising (1916) to house solely political prisoners until its final closure in the aftermath of the Irish Civil War (1922-1923) in early 1924. Usable data from the prison are available from the National Archives of Ireland for the period 1836 to 1910. Although initially a criminal prison that held men, women and children, its population changed over time. From the mid nineteenth century onwards it became the de facto holding centre for political prisoners in Ireland. ${ }^{\mathrm{F} 6}$ Notably Fenians were the first group of political prisoners to be held en masse in the 1860s and Land League leaders - most famously Charles Stewart Parnell MP, leader of the Irish Parliamentary Party - were held there in a large, single cell in the $1880 \mathrm{~s}$. The prison stopped housing women and children in the $1880 \mathrm{~s}$. Despite contemporary interest in the political associations of Kilmainham Gaol's past prisoners it should be emphasized that over the history of the prison the overwhelming majority of prisoners were criminal.

\footnotetext{
${ }^{\text {F5 }}$ Carroll-Burke, Colonial discipline, pp. 95-131.

${ }^{\mathrm{F} 6}$ Cooke, A History.
} 


\section{Footnote references}

Carroll-Burke, P., Colonial discipline: the making of the Irish convict system (Dublin, 2000).

Cooke, P., A history of Kilmainham Gaol, 1796-1924 (Dublin, 1995).

Jordan, D., Land and popular politics in Ireland: county Mayo from the Plantation to the Land War (Cambridge, 1994).

Mokyr, J., Why Ireland starved: a quantitative and analytical history of the Irish economy, 1800-1850 (2nd edition, 1985).

Ó Gráda, C., Ireland: A New Economic History 1780-1939 (Oxford, 1995). 
Table S1: Delta computation using data from the 1841 and 1871 Mayo censuses and the Castlebar Gaol registers

\begin{tabular}{|c|c|c|c|c|}
\hline \multirow[t]{2}{*}{$\begin{array}{l}\text { Birth } \\
\text { cohort }\end{array}$} & \multicolumn{2}{|c|}{$\begin{array}{c}\text { Prisoners } \\
\text { (full population) }\end{array}$} & \multicolumn{2}{|c|}{$\begin{array}{l}\text { Prisoners } \\
\text { (drunkards) }\end{array}$} \\
\hline & (1841 census) & (1871 census) & (1841 census) & (1871 census) \\
\hline \multirow{2}{*}{\multicolumn{5}{|c|}{$\begin{array}{l}1780 \\
1790\end{array}$}} \\
\hline & & & & \\
\hline \multicolumn{5}{|l|}{1800} \\
\hline 1810 & 28.3 & 34.6 & & \\
\hline 1820 & & 21.5 & & 35.2 \\
\hline 1830 & & 5.1 & & 1.3 \\
\hline 1840 & & -8.4 & & -5.9 \\
\hline
\end{tabular}

Notes: All individuals in dataset were imprisoned post-1870. Mean and median values for all deltas shown are 14.0 and 13.3.

Sources: See footnote F1.

Table S2: Delta computation using the 1841 and 1871 Dublin County censuses and Kilmainham Gaol registers

\begin{tabular}{|c|c|c|c|c|c|c|}
\hline \multirow[t]{2}{*}{$\begin{array}{l}\text { Birth } \\
\text { cohort }\end{array}$} & \multicolumn{2}{|c|}{$\begin{array}{c}\text { Prisoners } \\
\text { (full population) }\end{array}$} & \multicolumn{2}{|c|}{$\begin{array}{c}\text { Prisoners } \\
\text { (drunkards) }\end{array}$} & \multicolumn{2}{|c|}{$\begin{array}{c}\text { Prisoners } \\
\text { (imprisoned post-1870) }\end{array}$} \\
\hline & (1841 census) & (1871 census) & (1841 census) & (1871 census) & (1841 census) & (1871 census) \\
\hline 1780 & 11.1 & & & & & \\
\hline 1790 & 10.1 & & & & & \\
\hline 1800 & 23.1 & & & & & \\
\hline 1810 & 9.7 & 23.5 & 14.7 & 28.5 & 12.2 & 26.0 \\
\hline 1820 & & 16.1 & & 22.4 & & 28.6 \\
\hline 1830 & & 11.5 & & 29.0 & & 32.8 \\
\hline 1840 & & 1.6 & & 10.4 & & 6.6 \\
\hline
\end{tabular}

Notes: Mean and median values for all deltas shown are 17.7 and 15.4.

Sources: See footnote F1. 